\title{
ANALISIS KINERJA KEUANGAN PADA KLUB SEPAK BOLA (STUDI KASUS PADA ARSENAL, TOTTENHAM HOTSPUR DAN EVERTON)
}

\author{
Elvina Chandra Pranata \\ Alumnus Fakultas Ekonomika dan Bisnis, Universitas Kristen Satya Wacana \\ Supatmi \\ Fakultas Ekonomika dan Bisnis, Universitas Kristen Satya Wacana \\ patmie@staff.uksw.edu
}

\begin{abstract}
Football is a popular sport that affect various aspects of life, one of which is the economy. In Europe, football has become an industry and the clubs most are already preparing financial statements. This study aims to analyze the financial performance of three football clubs that followed the Premier League as one of the best leagues in the world, Arsenal, Tottenham Hotspurs and Everton, for the period of 2007-2011. This study uses the technique of quantitative and qualitative descriptive analysis using 14 financial ratios relevant to the football club. Results showed in general Arsenal is a club that has the best financial performance in comparison Tottenham Hotspurs and Everton, in particular in such matters, income and liquidity. Tottenham Hotspurs have advantages in terms of net investment over player contracts and operating cash flow. While Everton in general have the worst financial performance in terms of operations and liquidity, but has a good asset turn over.
\end{abstract}

Keywords: financial performance, football club

\section{PENDAHULUAN}

Sepak bola adalah olah raga yang paling digemari di dunia. Survey yang dilakukan oleh Federation of International Football Association (FIFA) pada tahun 2001 yang menunjukkan lebih dari 240 juta orang di 200 negara di hampir setiap bagian dunia, memainkan sepak bola (http://most-popular.net/Sport-Played-World). Sepak bola terus berkembang hingga hampir ke semua aspek kehidupan di dunia ini, termasuk di antaranya bidang ekonomi dan bisnis. Hidayat (2010) mengatakan akhir-akhir ini pengaruh sepak bola menonjol di bidang ekonomi, khususnya bisnis. Bisnis sepak bola terutama berkembang di negara-negara Eropa. Perkembangan bisnis sepak bola di negara-negara Eropa didukung dengan kepopuleran sepak bola di negara-negara Eropa. 
Kepopuleran klub-klub sepak bola berdampak pada pendapatan yang diperoleh oleh klub tersebut. Penghasilan klub sepak bola di Inggris tidak hanya dari penjualan tiket pertandingan. Secara garis besar pendapatan klub sepak bola berasal dari tiga sumber utama: pemasukan dari penjualan tiket, pendapatan hak siar TV dan komersial, termasuk sponsorships dan penjualan merchandise. Sewajarnya sebuah klub memiliki ketiga sumber pendapatan secara seimbang, yaitu masing-masing sumber menyumbang sepertiga dari pendapatan klub.

Kefanatikkan penggemar sepak bola mengusik klub-klub sepak bola untuk berbisnis merchandise seperti lencana, syal, jersey, patung-patung, bola dan produk merchandise lainnya. Keberadaan sumber pendapatan yang banyak tersebut tentu membuat publik penasaran bagaimana sebuah klub sepak bola melaporkan pendapatan yang diperoleh (http://www.sepaxbola.info/2011). Perkembangannya dapat dilihat, bahwa beberapa sepak bola tersebut tidak hanya menarik bagi perusahaan-perusahaan untuk menjadi sponsor, namun juga menarik pengusahapengusaha terkenal untuk masuk ke bisnis ini. Sebagai contoh Roman Abramovich (Chelsea), Alisher Usmanov (Arsenal), Silvio Berlusconi (AC Milan), Malcolm Glazer (Manchester United) dan lain-lain (http://www.lintasbola.net). Bahkan menurut www.tempo.co.id pada tahun 2013 ada tiga pengusaha Indonesia yang mengakuisisi 70 persen saham klub sepak bola Inter Milan.

Hidayat (2010) mengatakan popularitas klub-klub yang ada tentu juga membuat pemain-pemain yang bermain di klub terbawa menjadi populer juga. Tetapi ada juga pemain yang lebih populer dari klubnya, seperti David Beckham dan Christiano Ronaldo yang seringkali lebih populer dari pada klubnya. Kepopuleran pemain juga memengaruhi pendapatan klub misalnya dengan menambahnya penjualan tiket karena ada pemain bintang yang berlaga, atau penjualan merchandise terkait sang pemain dan lain sebagainya. Kualitas dari pemain sekarang tidak menjadi satu-satunya alasan membeli seorang pemain tetapi kepopuleran dari pemain juga menjadi bahan pertimbangan.

Aktivitas klub sepak bola tergolong unik dan berbeda dengan industri pada umumnya, yang ini juga tercermin dalam laporan keuangannya. Beberapa penelitian tentang klub sepak bola, menyoroti keunikan industri ini terkait dengan akuntansi dan keuangannya. Dengan menggunakan 11 rasio keuangan, penelitian Amir dan Livne (2005) menemukan sebuah klub sepak bola melibatkan tiga aktivitas utama. Pertama, memperoleh pendapatan dari tiga sumber seperti yang telah disebutkan di atas yaitu dari penjualan tiket pertandingan, pendapatan hak siar TV dan komersial. Aktivitas kedua adalah jual-beli pemain sepak bola dan aktivitas ketiga mengembangkan dan mendidik in-house talent. Dari sisi aset, klub sepak bola memiliki aset tidak berwujud yang relatif besar dan hampir separuh dari aset yang terdapat di neraca. Aset tidak berwujudnya adalah kontrak pemain sepak bola dimana kontrak itu harus di amortisasi setiap tahunnya. Kontrak ini harus dihapus ketika pemain dijual atau habis masa kontraknya. 
Penelitian Aronsson et al. (2004) di Swedia senada dengan Amir dan Livne (2005) bahwa kontrak pemain harus dikapitalisasi sebagai aset tidak berwujud dan diperlakukan sesuai peraturan yang ada, sehingga ada tuntutan yang tinggi pada informasi yang diberikan di pengungkapan tambahan untuk memberikan informasi tentang nilai akuisisi, durasi kontrak rata-rata, akumulasi amortisasi, amortisasi setahun, nilai yang tercatat, undertaken write-downs dan struktur organisasi. Sedangkan penelitian Hidayat (2010) tentang kinerja keuangan atas klub sepak bola di Inggris (Arsenal), Italia (Juventus) dan Spanyol (Barcelona), menunjukkan bahwa proses bisnis yang dilakukan ketiga klub sama, tetapi sumber pendapatan utama Arsenal adalah dari penjualan tiket sementara dua klub lain dari hak siar televisi. Selain itu aset utama dari Arsenal adalah stadionnya, sementara itu Barcelona dan Juventus aset utamanya adalah kontrak pemain. Secara umum kinerja keuangan ketiga klub yang diukur dari current ratio, asset turn over dan rate of return to assets adalah baik, namun masih ada masalah dengan kemampuan meng-cover hutangnya.

Berdasarkan tiga penelitian di atas, penelitian ini menyoroti kembali aspek akuntansi dan keuangan pada klub sepak bola dengan menganalisis kinerja keuangan klub sepak bola di Inggris sebagai liga terbaik dibandingkan dengan semua liga yang ada (La Liga Spanyol, Seri A Italia, Bundesliga, Ligue 1 Francis, Eredivisie Belanda) (http://olahraga.kompasiana.com). Berdasarkan data publikasi laporan keuangan klub sepak bola di Liga Inggris selama tahun 2007-2011, ditemukan hanya ada tiga klub, yaitu Arsenal, Tottenham Hotspurs dan Everton, sehingga penelitian ini akan menganalisis kinerja keuangan ketiga klub tersebut. Penelitian ini tidak menggunakan rasio keuangan yang biasa digunakan oleh industri pada umumnya, namun rasio keuangan yang lebih fokus pada industri sepak bola sebagaimana yang digunakan oleh Amir dan Livne (2005) dan rasio keuangan terkait aset yang digunakan oleh Hidayat (2010). Hasil penelitian ini diharapkan dapat menggambarkan kinerja keuangan klub sepak bola untuk meningkatkan kinerja keuangannya dan menjadi masukkan serta best practice untuk laporan keuangan klub sepak bola di Indonesia.

\section{LANDASAN TEORI}

\section{Akuntansi Untuk Klub Sepak Bola}

Sebuah klub sepak bola seperti layaknya perusahaan lain, diwajibkan untuk melakukan pelaporan keuangan. Berbagai peraturan mengenai klub sepak bola dibuat oleh FIFA, termasuk peraturan mengenai financial criteria. Dalam Club Licensing Regulation (2007) yang dibuat FIFA disebutkan bahwa peraturan FIFA untuk sebuah klub yang akan lisensi dibagi menjadi dua bagian, pada bagian yang kedua disebutkan sebuah klub harus memenuhi beberapa kriteria minimum dari sporting criteria, infrastructure criteria, personnel and administrative criteria, legal criteria dan financial criteria sebagai bagian dari ketaatan klub dalam mengikuti kompetisi. Dalam rangka pemenuhan kriteria minimum tersebut sebuah klub sepak bola 
memerlukan pelaksanaan akuntansi untuk klubnya. Pelaksanaan akuntansi untuk klub sepak bola memerlukan prinsip akuntansi yang berlaku umum untuk sebuah klub sepak bola (www.fifa.com).

Tetapi, industri sepak bola tidak dibahas secara khusus dalam standar akuntansi, berbeda dengan industri lain yang dalam standar akuntansi terdapat pembahasan khusus. Oleh karena itu klub sepak bola harus memilah dan menentukan dari standar yang ada, standar yang mana saja yang dapat digunakan dan diterapkan. Walaupun demikian, Accounting For Football Club menyatakan bahwa walaupun semua akuntan dapat mengadopsi prinsip akuntansi yang berterima umum, akan tetapi setiap industri tetap memiliki ciri khasnya sendiri (www.oppapers.com/essays/Accounting-Football-Club/165074). Maka dari itu dibutuhkan pemahaman yang mendalam atas sebuah industri sehingga dapat memutuskan standar akuntansi mana yang paling memungkinkan untuk diterapkan dalam klub sepak bola, sehingga situasi keuangannya dapat tergambarkan dengan baik (www.oppapers.com/essays/Accounting-Football-Club/165074).

Peraturan mengenai akuntansi untuk sepak bola sudah ada di beberapa negara misalnya Swedia. Aronsson et al. (2004) mengatakan bahwa telah ada aturan pada asosiasi sepak bola Swedia walapun perlu untuk diperjelas dan pencapaiannya dibuat lebih mudah, bahkan menurut penelitian tersebut perlu adanya auditor untuk laporan keuangan klub sepak bola agar benar-benar sesuai dengan peraturan yang ada. Sebuah klub sepak bola tidak akan ada artinya jika tidak ada pemain sepak bola di dalamnya. Pemain sepak bola adalah salah satu item yang penting dari sebuah klub sepak bola.

Devi (2004) seperti yang dikutip oleh Hidayat (2010) berpendapat bahwa pemain sepak bola merupakan aset yang sangat penting bagi sebuah klub dan seharusnya pemain tersebut terdapat dalam neraca sebuah klub sepak bola. Tetapi beberapa tahun belakang ini terdapat perdebatan tentang apakah human capital seperti pemain sepak bola dapat dikategorikan sebagai aset perusahaan. Selanjutnya juga dinyatakan bahwa human capital dalam industri seperti sepak bola dapat memberikan nilai tambah bagi klub. Bahkan, nilai kontrak pemain sepak bola dapat mencapai setengah dari nilai aset yang dimiliki klub tersebut, sehingga jika nilai kontrak pemain tidak dilaporkan sebagai aset, maka aset yang ada di neraca tidak mencerminkan nilai aset klub yang sesungguhnya.

Pengakuan pemain sepak bola sebagai aset tidak berwujud masih menjadi pertentangan. Pemain sepak bola akan dapat dikategorikan sebagai aset tidak berwujud jika memenuhi kriteria dari sebuah aset tidak berwujud. Kriteria dari aset tidak berwujud menurut IAS 38 ada 2 yaitu: (1) kemungkinan besar entitas akan memperoleh manfaat ekonomis masa depan dari aset tersebut dan (2) biaya perolehan aset tersebut dapat diukur secara andal. Menurut Devi (2004) seperti dikutip Hidayat (2010) mengatakan bahwa berdasar kriteria aset yang ada, pemain sepak bola dapat dikategorikan sebagai aset, karena pemain sepak bola dapat dengan 
jelas diidentifikasi, sehingga dapat dijual, disewakan, dikendalikan, dipertukarkan secara terpisah dan memberikan manfaat masa depan. Manfaat masa depan yang dimaksud adalah kontribusi atau jasanya dalam membela klub tersebut di pertandingan selama dikontrak klub pemiliknya.

Aronsson et al. (2004) menyebutkan bahwa nilai akusisi kontrak harus mencakup semua biaya yang dikeluarkan untuk kontrak tersebut dan nilai kontrak tersebut harus dikapitalisasi sehingga kondisi klub lebih tergambar. Amir dan Livne (2005) menyebutkan hal yang sama bahwa pemain sepak bola sebagai aset harus dikapitalisasi. Selain dikapitalisasi, sebagai aset tidak berwujud, pemain sepak bola juga harus disusutkan. Amortisasi terhitung sejak tanggal ketika aset siap digunakan. Mengenai metoda amortisasi yang digunakan, IAS 38 menjelaskan bahwa terdapat beberapa metoda yaitu metoda garis lurus, metoda saldo menurun dan metoda unit produksi. Nilai yang dapat diamortisasi atas suatu aset dengan masa manfaat terbatas ditentukan setelah mengurangi nilai residunya.

Seperti aset yang harus dihilangkan dari neraca ketika masa manfaatnya habis, seorang pemain sepak bola yang telah habis masa kontraknya atau dijual kepada klub lain, maka aset tersebut harus dihilangkan dari neraca. IAS 38 menyatakan bahwa sebuah aset tak berwujud tidak boleh diakui lagi dan harus dihilangkan dari neraca, ketika aset tersebut dilepas atau ketika tidak ada lagi manfaat masa depan yang diharapkan dari penggunaannya dan pelepasan yang dilakukan setelahnya. Pemain sepak bola yang sudah diakui sebagai aset perusahaan harus diungkapkan dalam laporan keuangan. IAS 38 memberikan arahan bahwa laporan keuangan harus mengungkapkan hal-hal berikut untuk setiap golongan aset tidak berwujud, dengan membedakan antara aset tidak berwujud yang dihasilkan secara intern dan aset tidak berwujud lainnya.

Jenis laporan keuangan yang harus ada dalam laporan keuangan tahunan menurut aturan Club Licensing Regulation (2007) oleh FIFA adalah Balance Sheets, Consolidated Profit and Loss Account dan Notes to the Accounts. Notes to the Accounts harus mengungkapkan tentang accounting policies, controlling party, ultimate owner, related-party transactions dan other disclosure. Sementara pada kenyataannya klub sepak bola di Inggris menerbitkan laporan keuangan tahunan yang terdiri dari: consolidated Profit \& Loss Account, Balance Sheets, Consolidated Cash Flow Statement dan Notes to the Accounts.

\section{Kinerja Keuangan Klub Sepak Bola}

Kinerja keuangan menurut Helfert (2000) seperti dikutip Kurniawan (2007), adalah suatu hasil, prestasi ataupun keadaan yang telah dicapai perusahaan selama satu periode atau satu kurun waktu tertentu. Kinerja keuangan diukur dengan menggunakan data-data yang ada dalam neraca dan laba-rugi. Alat pengukuran yang paling sering digunakan adalah rasio. Penelitian ini menggunakan 14 rasio keuangan, yaitu 11 rasio keuangan yang mengacu kepada penelitian Amir dan Livne (2005) dan 
tiga rasio keuangan yang mengacu pada penelitian Hidayat (2010), yang secara rinci dijabarkan pada bagian metoda penelitian.

Penelitian Hidayat (2010) menunjukkan bahwa ketiga klub menyusun laporan keuangan sebagai laporan atas hasil transaksi bisnisnya. Sumber pemasukan Juventus dan Barcelona berasal dari hak siar televisi, Arsenal dari penjualan tiket karena kapasitas stadionnya yang cukup besar dan harga tiket yang mahal. Dalam hal pengeluaran, ketiga klub sama-sama paling banyak mengeluarkan uang mereka untuk membayar gaji pemain. Dengan menggunakan tiga rasio keuangan, yaitu current ratio, asset turnover dan rate of return to assets, hasil penelitian Hidayat (2010) juga menunjukkan komponen aset terbesar Arsenal berupa stadion sepak bola, sementara pemain sepak bola adalah komponen aset yang paling dominan bagi Juventus dan Barcelona. Ketiga klub mengakui pemain sepak bola sebagai aset tidak berwujud dan dicatat sebesar harga perolehan, kemudian diamortisasi sepanjang masa kontrak pemain. Pemain sepak bola dilaporkan sebesar net book value mereka. Selanjutnya, arus kas operasi ketiga klub positif tetapi Barcelona terpaksa melakukan pendanaan dengan meminjam karena kegiatan investasi yang besar. Kemampuan klub dalam mengcover hutang perlu diperhatikan. Hal ini terutama terjadi pada klub Arsenal dan Barcelona. Meski demikian klub Arsenal tercatat memiliki profitabilitas yang tinggi dibanding Barcelona dan Juventus.

Penelitian Amir dan Livne (2005) menemukan sebuah klub sepak bola melibatkan tiga aktivitas utama, yaitu pendapatan yang berasal dari tiga sumber (penjualan tiket pertandingan, pendapatan hak siar TV dan komersial), jual-beli pemain sepak bola dan mengembangkan dan mendidik in-house talent. Aset tidak berwujud yang berupa kontrak pemain sepak bola merupakan aset yang besar porsinya di neraca. Selanjutnya berdasarkan 11 rasio keuangan yang digunakan, hasil penelitian Amir dan Livne (2005) menunjukkan bahwa angka penjualan yang meningkat, mencerminkan pertumbuhan industri sepak bola. Kinerja keuangan yang diukur dari median sales, operating profit margin before transfer fees, biaya kontrak pemain, intangible intensity ratio dan operating cash flow pada listed company lebih besar dari private company. Lebih dari setengah pendapatan klub digunakan untuk membayar upah dan proporsi upah meningkat dari waktu ke waktu. Listed company membayar upah lebih rendah dari pada private company pada ketiga sub periode walaupun kontribusi marjinal pemain lebih besar pada listed company. Biaya kontrak pemain merupakan pengeluaran terbesar kedua. Financial leverage ratio semua perusahaan sangat tinggi, namun rata-rata intangible intensity ratio adalah 20 persen, yang berarti bahwa kontrak pemain adalah bagian yang penting dalam sebuah klub sepak bola.

Hasil penelitian Amir dan Livne (2005) juga menunjukkan bahwa klub yang mengikuti Premier League menghasilkan kerugian dari perdagangan pemain, dimana kerugian diukur dengan investasi pada pemain dikurangi pendapatan dari penjualan pemain. Tim di divisi yang lebih rendah, sebaliknya menghasilkan keuntungan dari 
perdagangan pemain. Hasil ini menyoroti dua strategi yang berbeda yang digunakan oleh klub sepak bola di Inggris dalam memanfaatkan bakat, yaitu perusahaan besar tampaknya berinvestasi pada kontrak pemain untuk mempertahankan posisi liga sedangkan perusahaan kecil melakukan perdagangan kontrak pemain untuk mempertahankan liabilitas keuangan mereka.

\section{METODA PENELITIAN}

Penelitian ini menganalisis kinerja keuangan tiga klub sepak bola di Inggris, yaitu Everton, Tottenham Hotspurs dan Arsenal. Dari 20 klub yang mengikuti Barclays Premiere League, hanya tiga klub tersebut yang menerbitkan laporan keuangan secara lengkap selama tahun 2007-2011. Jenis data yang digunakan yaitu data sekunder berupa laporan keuangan tahunan klub sepak bola tahun 2007-2011. Laporan keuangan ini di dapat dari situs resmi klub yang bersangkutan yaitu www.evertonfc.com untuk Everton, www.tottenhamhotspurs.com untuk Tottenham Hotspurs dan www.arsenal.com untuk Arsenal.

Penelitian ini akan menggunakan rasio keuangan klub sepak bola sebagai alat untuk mengukur kinerja keuangan klub sepak bola. Rasio keuangan yang digunakan mengacu pada sebelas rasio keuangan yang digunakan dalam penelitian Amir dan Livne (2005) dan tiga rasio keuangan menurut Hidayat (2010) yang meliputi current ratio, asset turnover dan rate of return to assets. Berikut ini pengukuran rasio-rasio keuangan yang digunakan dalam penelitian ini:

Current sales ratio, yaitu rasio yang mengukur peningkatan penjualan, yang dihitung dengan membandingkan penjualan tahun berjalan terhadap penjualan tahun sebelumnya. Operating profit before transfer fees ratio, yaitu rasio yang mengukur seberapa besar penjualan tahun tertentu menghasilkan laba operasi, yang dihitung dengan membandingkan penjualan dikurangi dengan biaya gaji dan biaya operasional, dibagi dengan total penjualan. Adjusted cash flows from operations ratio, yaitu rasio yang mengukur pengaruh penjualan tahun tertentu terhadap arus kas operasi, yang dirumuskan dengan adjusted cash flow from operations dibagi dengan penjualan. Current wages ratio, yaitu rasio yang mengukur seberapa besar penjualan periode tertentu yang digunakan untuk membiayai beban gaji, yang dihitung dengan beban gaji dibagi total pendapatan. total assets to total sales ratio, yaitu rasio yang membadingkan total aset dengan penjualan tahun sebelumnya. Investment in player contracts, yaitu rasio yang mengukur seberapa besar penjualan periode tertentu yang digunakan untuk membeli dan membayar kontrak pemain. Cash received from selling player contract, yaitu rasio yang menunjukkan seberapa besar penjualan pada periode tertentu yang diperoleh dari penjualan pemain. Net investment in player contracts, yaitu rasio yang digunakan untuk mengetahui selisih antara penjualan dan pembelian pemain. Adjusted leverage, yaitu rasio yang membagi jumlah kewajiban dengan total aset (setelah kapitalisasi kontrak pemain dikeluarkan). Rasio ini 
menunjukkan seberapa besar aset dapat dibiayai dengan utangnya. Contract amortitation rate, yaitu rasio yang mengukur tingkat amortisasi kontrak permain, yang dihitung dengan membagi amortisasi kontrak pemain ditambah kontrak writeoff, dengan biaya kontrak pemain. Intangible intensity, yaitu rasio ini untuk melihat seberapa besar proporsi kontrak pemain sepak bola dalam total aset, yang di hitung dengan cara biaya kontrak pemain dikurangi dengan akumulasi amortisasi, kemudian dibagi dengan total aset. Current ratio, yaitu rasio yang menunjukkan kemampuan perusahaan untuk melunasi hutang lancar dengan menggunakan aset lancarnya, yang dihitung dengan membagi current assets terhadap current liabilities. Assets turnover, yaitu rasio yang membagi penjualan bersih dengan total aset. Rate of return to assets, yaitu rasio yang menunjukkan kemampuan klub dalam memanfaatkan aset yang dimilikinya untuk memperoleh laba.

Dalam rasio operating profit before transfer fees, adjusted cash flows from operations, current wages, investment in player contracts dan cash received from selling player contract, analisis akan dilihat posisi rasio tersebut pada tahun berjalan dan tahun sebelumnya. Teknik analisis yang digunakan dalam penelitian ini adalah analisis deskriptif kuantitatif dan kualitatif terhadap laporan tahunan tiga klub (Everton, Tottenham Hotspur dan Arsenal) dengan menggunakan 14 rasio keuangan.

\section{ANALISIS DAN PEMBAHASAN}

Berikut ini akan dijabarkan pembahasan rasio keuangan yang diperoleh dari hasil pengolahan data laporan keuangan tahunan Arsenal, Tottenham Hotspurs dan Everton selama tahun 2007-2011 untuk setiap rasio keuangan:

\section{Current Sales}

Rasio ini adalah rasio yang digunakan untuk mengukur peningkatan penjualan selama periode tertentu. Berikut rata-rata current sales dan rata-rata setiap komponen sales untuk Tottenham Hotspurs, Arsenal dan Everton untuk tahun 20072011.

Tabel 1

Rata- rata Current Sales dan Komponennya

\begin{tabular}{cccccc}
\hline Nama Klub & Current Sales & $\begin{array}{c}\text { Pendapatan } \\
\text { Tiket }\end{array}$ & $\begin{array}{c}\text { Pendapatan } \\
\text { Hak Siar }\end{array}$ & $\begin{array}{c}\text { Pendaptan } \\
\text { Komersial }\end{array}$ & $\begin{array}{c}\text { Pendapatan } \\
\text { lain - lain }\end{array}$ \\
\hline $\begin{array}{c}\text { Arsenal } \\
\text { Tottenham }\end{array}$ & $117,29 \%$ & $121,73 \%$ & $111,69 \%$ & $108,40 \%$ & $173,72 \%$ \\
Hotspurs & $118,26 \%$ & $136,66 \%$ & $113,61 \%$ & $116,68 \%$ & $107,56 \%$ \\
Everton & $108,78 \%$ & $99,95 \%$ & $117,38 \%$ & $106,10 \%$ & $107,35 \%$ \\
\hline
\end{tabular}

Sumber: Data diolah, 2012

Dari Tabel 1, rata-rata current sales Tottenham Hotspurs yang terbesar, diikuti dengan Arsenal dan yang terkecil adalah Everton, ini berarti rata-rata 
pertumbuhan penjualan Tottenham Hotspurs selama lima tahun terakhir adalah yang paling tinggi dibandingkan dengan kedua klub lainnya. Hal ini juga dapat dilihat dalam Grafik 1.

Dari Grafik 1 terlihat current sales ketiga klub berfluktuasi. Akan tetapi, Tottenham Hotspurs cenderung mengalami kenaikkan dan dua klub lainnya mengalami penurunan. Kenaikkan pada current sales Tottenham Hotspurs dan penurunan pada current sales Arsenal dan Everton disebabkan karena perubahan pada komponen pendapatannya, sebagaimana ditunjukkan dalam Grafik 2.

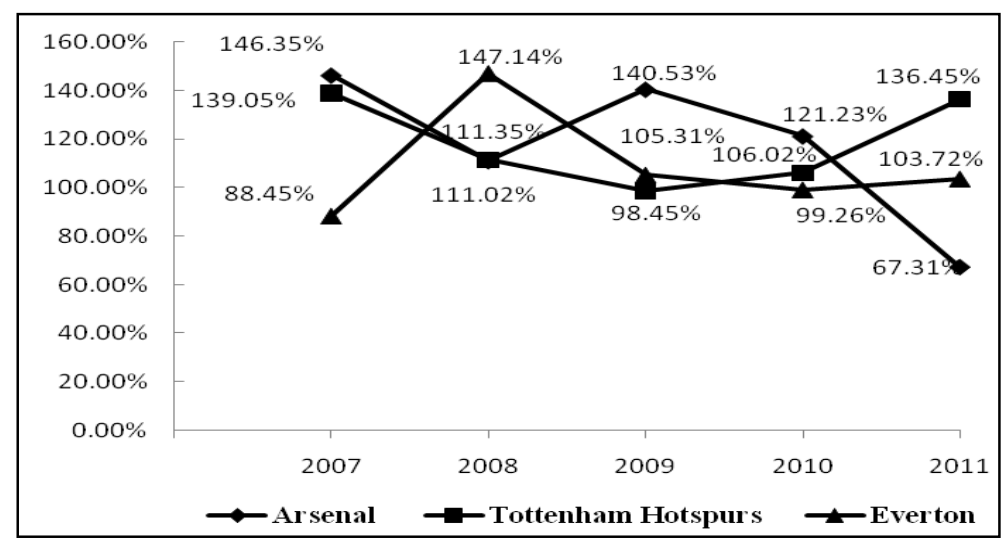

Grafik 1

Current Sales

Dari Grafik 2 terlihat bahwa, current sales Tottenham Hotspurs mengalami kenaikkan karena pendapatan tiket dan pendapatan komersial Tottenham Hotspurs mengalami kenaikkan yang signifikan dan hanya mengalami sedikit penurunan pada pendapatan hak siar dan pendapatan lain-lain. Selain itu, penurunan current sales Arsenal terjadi karena pendapatan hak siar dan pendapatan lain-lain seperti property development menurun secara signifikan, sementara pendapatan tiket pendapatan hak siar hanya mengalami kenaikkan sedikit. Current sales Everton mengalami penurunan karena pendapatan komersial Everton mengalami penurunan sementara pendapatan tiket, pendapatan hak siar dan pendapatan lain-lain hanya naik sedikit.

Secara rata-rata dapat disimpulkan bahwa current sales yang terbaik dimiliki Tottenham Hotspurs dan terburuk adalah Everton. Komponen pendapatan terbesar Tottenham Hotspur dan Everton adalah dari hak siar yaitu sebesar 36,71 persen dan 60,81 persen, sementara Arsenal bersumber dari penjualan tiket sebesar 36,12 persen. Penjualan tiket yang besar dari Arsenal dikarenakan stadion Arsenal yang baru dan memuat banyak suporter, sementara Tottenham Hotspurs pendapatan hak siarnya memberi kontribusi terbesar karena adanya kesepakatan dengan Football Assosiation Premier League (FAPL) TV dan Everton sumber pendapatan terbesarnya dari hak siar karena ada kesepakatan dengan hak siar liga primer di televisi. 


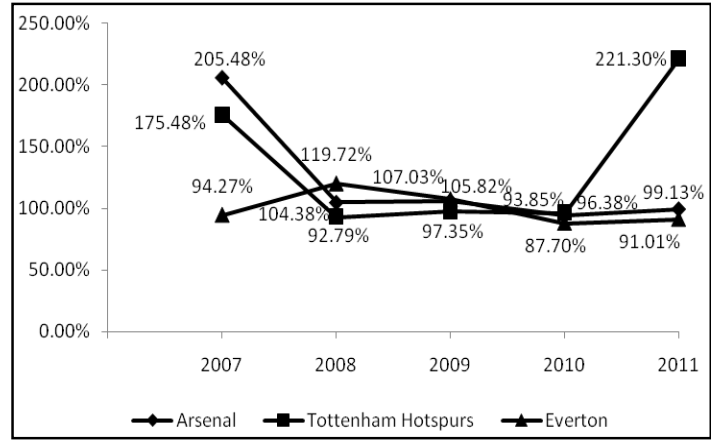

Pendapatan Tiket

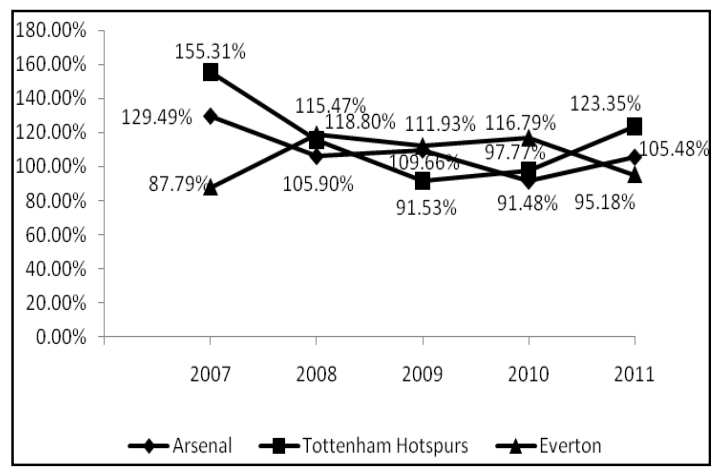

Pendapatan

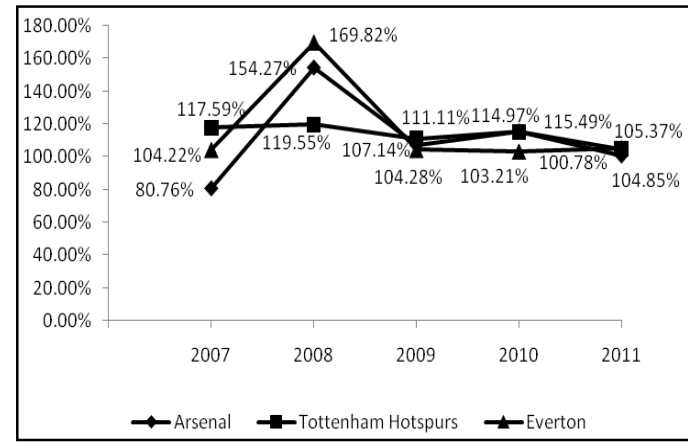

Pendapatan Hak Siar

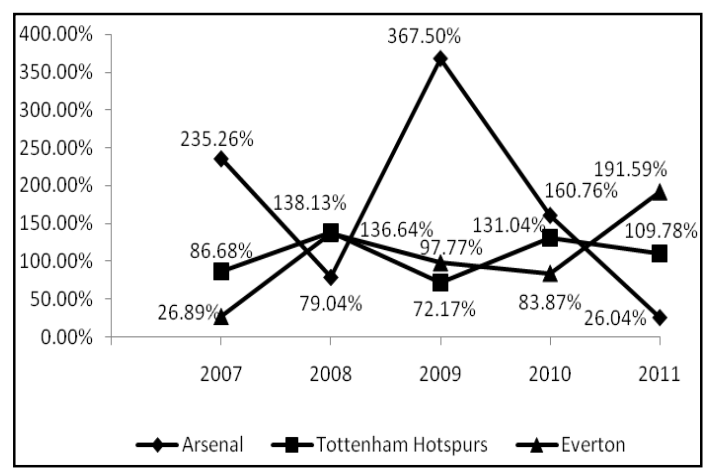

Pendapatan lain-lain

Grafik 2

Current Sales Setiap Komponen Pendapatan

\section{Operating Profit Before Transfer Fees Ratio}

Rasio ini adalah rasio yang digunakan untuk mengukur laba operasi. Rasio ini membagi laba sebelum biaya transfer, beban bunga dan pajak, dengan total penjualan pada periode tertentu. Melalui rasio ini dapat diketahui laba operasi yang dihasilkan oleh penjualan tahun tersebut dan penjualan tahun sebelumnya. Tabel operating profit before transfer fees tahun tertentu $\left(O P R O F_{t}\right)$ dan operating profit before transfer fees tahun sebelumnya $\left(O P R O F_{t-1}\right)$ dari Tottenham Hotspurs, Arsenal dan Everton untuk tahun 2007-2011.

Tabel 2

Operating Profit Before Transfer Fees Tahun Tertentu (t) dan Operating Profit Before Transfer Fees Tahun Sebelumnya (t-1)

\begin{tabular}{cccccccc}
\hline Nama Klub & Rasio & $\mathbf{2 0 0 7}$ & $\mathbf{2 0 0 8}$ & $\mathbf{2 0 0 9}$ & $\mathbf{2 0 1 0}$ & $\mathbf{2 0 1 1}$ & Rata-rata \\
\hline \multirow{2}{*}{ Arsenal } & OPROF $_{t}$ & $11,64 \%$ & $11,99 \%$ & $12,29 \%$ & $9,36 \%$ & $8,57 \%$ & $10,77 \%$ \\
& OPROF $_{t-1}$ & $17,03 \%$ & $13,31 \%$ & $17,27 \%$ & $11,35 \%$ & $5,77 \%$ & $12,95 \%$ \\
Tottenham & OPROF $_{t}$ & $10,32 \%$ & $-8,28 \%$ & $-17,44 \%$ & $-14,02 \%$ & $-4,38 \%$ & $-6,76 \%$ \\
Hotspurs & OPROF $_{t-1}$ & $14,36 \%$ & $-9,22 \%$ & $-17,17 \%$ & $-14,86 \%$ & $-5,97 \%$ & $-6,57 \%$ \\
\multirow{2}{*}{ Everton } & OPROF $_{t}$ & $-21,28 \%$ & $-7,32 \%$ & $-8,48 \%$ & $-22,38 \%$ & $-20,91 \%$ & $-16,08 \%$ \\
& OPROF $_{t-1}$ & $-18,83 \%$ & $-10,78 \%$ & $-8,93 \%$ & $-22,21 \%$ & $-21,69 \%$ & $-16,49 \%$ \\
\hline
\end{tabular}

Sumber: Data diolah, 2012 
Berdasarkan Tabel 2, terlihat bahwa rata-rata $O P R O F_{t}$ dan $O P R O F_{t-1}$ Arsenal adalah yang paling besar diantara yang lain, diikuti Tottenham Hotspurs, yang terkecil adalah Everton, ini berarti rata-rata dari laba operasi dibandingkan penjualan Arsenal selama lima tahun terakhir adalah yang paling tinggi dibandingkan dengan kedua klub lainnya. Hal ini juga dapat dilihat dalam Grafik 3.

Dari Grafik 3, $O P R O F_{t}$ dan $O P R O F_{t-1}$ ketiga klub berfluktuasi, tetapi Arsenal cederung mengalami sedikit penurunan, sedangkan dua klub lainnya berada di posisi rugi. Penurunan $O P R O F_{t}$ dan $O P R O F_{t-1}$ Arsenal terjadi karena gaji yang dibayarkan Arsenal semakin tinggi, sehingga laba operasinya semakin kecil. Sementara Tottenham Hotspurs hanya mengalami laba operasi di tahun 2007 karena sejak tahun 2008 gaji yang harus dibayarkan semakin besar terkait restruksturisasi pelatihnya dan investasi pemain. Tetapi pembayaran gaji tersebut mulai dapat tertutup oleh peningkatan sales pada tahun 2010, hal ini menyebabkan $O P R O F_{t}$ dan $O P R O F_{t-1}$ Tottenham Hotspurs mengalami kenaikkan. Sementara Everton selalu mengalami rugi operasi karena beban operasi Everton, terutama gaji selalu lebih besar dari salesnya.

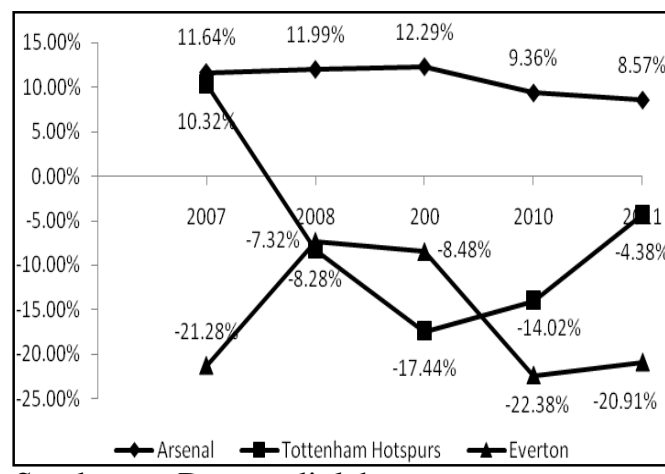

Sumber: Data diolah.

tahun $\mathrm{t}$

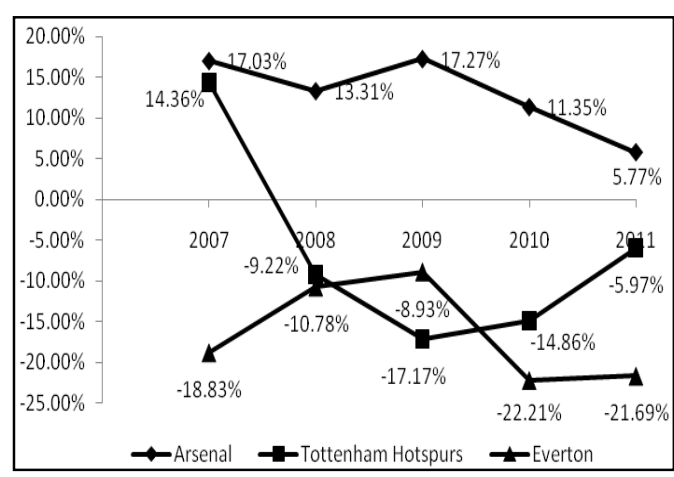

tahun t-1

Grafik 3

Operating Profit Before Transfer Fees Tahun Tertentu (t) dan Operating Profit Before Transfer Fees Tahun Sebelumnya $(\mathrm{t}-1)$

Secara rata-rata dapat disimpulkan bahwa $O P R O F_{t}$ dan $O P R O F_{t-1}$ Arsenal merupakan terbaik diantara yang lain, diikuti Tottenham Hotspurs dan terburuk adalah Everton. $O P R O F_{t}$ dan $O P R O F_{t-l}$ Arsenal berada di atas dua klub yang lainnya dan selalu menujukkan angka yang positif, yang berarti Arsenal selalu mampu untuk memperoleh laba operasi sepanjang 2007-2011, hal ini tidak lepas dari sales Arsenal yang besar dan dapat menutup beban operasinya. Sementara OPROF dan $O P R O F_{t-1}$ Everton adalah yang paling buruk karena sepanjang tahun 2007-2011 mengalami kerugian dari operasi karena walaupun salesnya mengalami kenaikkan, beban operasi yang harus ditanggung Everton selalu lebih besar dari pada salesnya. Beban operasi Everton besar karena selain beban gaji yang dibayarkan Everton besar, beban operasi lain-lain Everton juga besar. 


\section{Adjusted cash flow from operation ratio}

Rasio ini adalah rasio yang digunakan untuk mengukur arus kas operasi. Adjusted cash flow dihitung dari kas dari operasi sebelum pajak bunga dan biaya transfer. Melalui rasio ini dapat diketahui penjualan tahun tersebut dan tahun sebelumnya yang berasal dari kegiatan operasi. Berikut tabel adjusted cash flow from operation tahun tertentu $\left(A C F O_{t}\right)$ dan adjusted cash flow from operation tahun sebelumnya $\left(A C F O_{t-1}\right)$ dari Tottenham Hotspurs, Everton dan Arsenal untuk tahun 2007-2011.

Dari Tabel 3, rata-rata $A C F O_{t}$ dan $A C F O_{t-1}$ yang paling besar adalah Tottenham Hotspurs, diikuti Arsenal dan terkecil adalah Everton, ini berarti rata-rata dari arus kas operasi dibandingkan penjualan Tottenham Hotspurs selama lima tahun terakhir adalah yang paling tinggi dibandingkan dengan kedua klub lainnya. Hal ini juga dapat dilihat di Grafik 4.

Tabel 3

Adjusted Cash Flow from Operation Tahun Tertentu (t) dan Adjusted Cash Flow from Operation Tahun Sebelumnya (t-1)

\begin{tabular}{cccccccc}
\hline Nama Klub & Rasio & $\mathbf{2 0 0 7}$ & $\mathbf{2 0 0 8}$ & $\mathbf{2 0 0 9}$ & $\mathbf{2 0 1 0}$ & $\mathbf{2 0 1 1}$ & Rata-rata \\
\hline \multirow{2}{*}{ Arsenal } & $A C F O_{t}$ & $38,50 \%$ & $-9,42 \%$ & $19,88 \%$ & $46,48 \%$ & $20,78 \%$ & $23,25 \%$ \\
& $A C F O_{t-1}$ & $56,35 \%$ & $-10,46 \%$ & $27,94 \%$ & $56,35 \%$ & $13,99 \%$ & $28,83 \%$ \\
Tottenham & $A C F O_{t}$ & $8,27 \%$ & $30,71 \%$ & $26,50 \%$ & $16,57 \%$ & $42,26 \%$ & $24,86 \%$ \\
Hotspurs & $A C F O_{t-1}$ & $11,50 \%$ & $34,19 \%$ & $26,09 \%$ & $17,57 \%$ & $57,66 \%$ & $29,40 \%$ \\
& $A C F O_{t}$ & $5,31 \%$ & $14,03 \%$ & $12,11 \%$ & $1,80 \%$ & $2,32 \%$ & $7,12 \%$ \\
Everton & $A C F O_{t-1}$ & $4,70 \%$ & $20,64 \%$ & $12,76 \%$ & $1,79 \%$ & $2,41 \%$ & $8,46 \%$ \\
\hline
\end{tabular}

Sumber: Data diolah,2012

Berdasarkan Grafik 4, adjusted cash flow from operation dari ketiga klub yang berfluktuasi. Penurunan adjusted cash flow from operation Arsenal yang paling drastis terjadi di tahun 2008, karena peningkatan dalam persediaan pengembangan properti yang berarti ada pembelian persediaan yang menyebabkan pengeluaran kas. Cash flow from operation Arsenal kembali naik di tahun 2010 karena persediaan pengembangan properti mengalami penurunan, yang berarti ada penjualan persediaan yang menyebabkan kas masuk. Kenaikkan adjusted cash flow from operation dari Tottenham Hotspurs pada tahun 2011 terjadi karena kenaikkan pada perdagangan dan hutang lain-lain, sementara kenaikkan adjusted cash flow from operation pada tahun 2011 dari Everton terjadi karena kerugian operasi yang dialami Everton turun sehingga menyebabkan adjusted cash flow from operation naik.

Dapat disimpulkan bahwa secara rata-rata adjusted cash flow from operation paling baik adalah Tottenham Hotspurs karena perubahan adjusted cash flow Tottenham Hotspurs lebih stabil dari pada Arsenal dan selalu berada di atas Everton. Sementara Adjusted cash flow from operation dari Everton yang paling buruk karena berada di bawah kedua klub lainnya, yang berarti hanya sedikit arus kas operasi yang dihasilkan. 


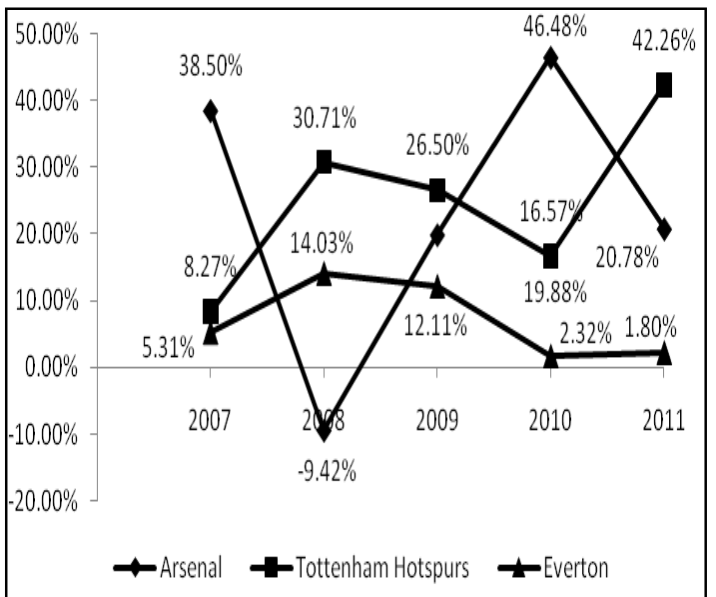

tahun $\mathbf{t}$

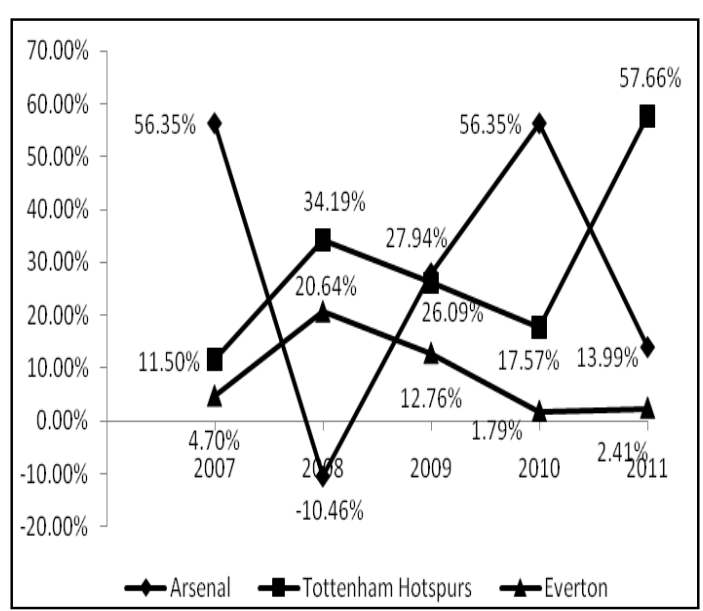

tahun t-1

Grafik 4

Adjusted Cash Flow from Operation Tahun Tertentu (t) dan Adjusted Cash Flow from Operation Tahun Sebelumnya (t-1)

\section{Current Wages Ratio}

Rasio ini adalah rasio yang mengukur seberapa besar penjualan periode tertentu yang digunakan untuk membiayai beban gaji. Berikut tabel current wages

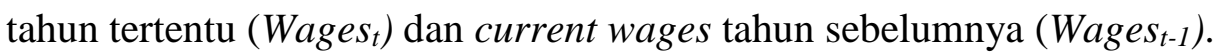

Tabel 4

Current Wages Tahun Tertentu (t) dan Current Wages Tahun Sebelumnya (t-1)

\begin{tabular}{cccccccc}
\hline Nama Klub & Rasio & $\mathbf{2 0 0 7}$ & $\mathbf{2 0 0 8}$ & $\mathbf{2 0 0 9}$ & $\mathbf{2 0 1 0}$ & $\mathbf{2 0 1 1}$ & $\begin{array}{c}\text { Rata- } \\
\text { rata }\end{array}$ \\
\hline \multirow{2}{*}{ Arsenal } & Wages $_{t}$ & $38,66 \%$ & $39,58 \%$ & $28,94 \%$ & $25,44 \%$ & $42,86 \%$ & $35,10 \%$ \\
\multirow{2}{*}{ Tottenham } & Wages $_{t-1}$ & $56,58 \%$ & $43,94 \%$ & $40,67 \%$ & $30,85 \%$ & $28,85 \%$ & $40,18 \%$ \\
Hotspurs & Wages $_{t}$ & $37,96 \%$ & $41,32 \%$ & $47,41 \%$ & $49,58 \%$ & $48,36 \%$ & $44,93 \%$ \\
\multirow{2}{*}{ Everton } & Wages $_{t-1}$ & $52,79 \%$ & $46,01 \%$ & $46,67 \%$ & $52,57 \%$ & $65,98 \%$ & $52,80 \%$ \\
& Wages $_{t}$ & $66,51 \%$ & $51,92 \%$ & $54,54 \%$ & $60,01 \%$ & $60,02 \%$ & $58,60 \%$ \\
& Wages $_{t-1}$ & $58,83 \%$ & $76,39 \%$ & $57,43 \%$ & $59,56 \%$ & $62,25 \%$ & $62,89 \%$ \\
\hline
\end{tabular}

Sumber: Data diolah, 2012

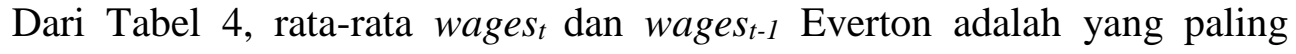
besar, diikuti Tottenham Hotspurs dan terkecil adalah Arsenal, ini berarti rata-rata dari beban gaji dibandingkan penjualan Everton selama lima tahun terakhir adalah yang paling tinggi dibandingkan dengan kedua klub lainnya. Hal ini juga dapat dilihat dalam grafik Wages $_{t}$ dan Wagest-1 pada Grafik 5. 
Secara rata-rata dapat disimpulkan bahwa rasio current wages Arsenal adalah yang paling baik karena walaupun gajinya paling besar diantara yang lain tetapi, selisih penjualan dengan gajinya adalah yang paling besar dibanding yang lain yang berarti pembayaran gajinya yang besar diimbangi dengan penjualan yang besar juga. Sementara current wages dari Everton adalah yang paling buruk karena walaupun gajinya lebih rendah diantara klub yang lain tetapi selisih antara penjualan dengan gajinya adalah yang paling kecil diantara yang lain yang berarti kenaikkan pembayaran gajinya kurang diimbangi dengan kenaikkan penjualannya.

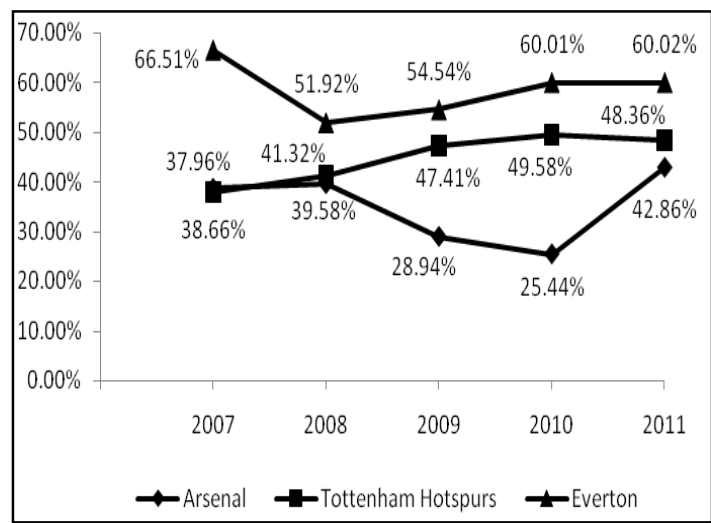

tahun $\mathrm{t}$

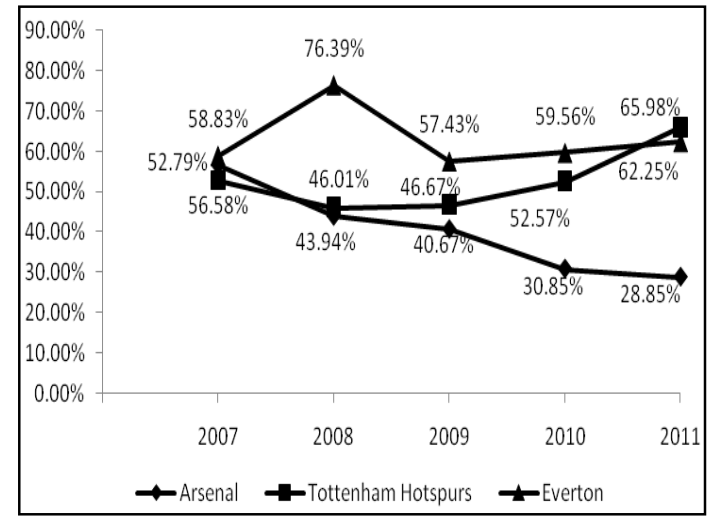

tahun $\mathrm{t}-1$

Grafik 5

Current Wages Tahun Tertentu (t) dan Current Wages Tahun Tebelumnya (t-1)

\section{Total Assets to Total Sales Ratio}

Rasio ini adalah rasio yang membandingkan total aset dengan penjualan tahun sebelumnya. Berikut grafik dan tabel total aset tahun 2007-2011 dari Tottenham Hotspurs, Arsenal dan Everton.

Tabel 5

Total Assets to Total Sales Ratio

\begin{tabular}{ccccccc}
\hline Nama Klub & $\mathbf{2 0 0 7}$ & $\mathbf{2 0 0 8}$ & $\mathbf{2 0 0 9}$ & $\mathbf{2 0 1 0}$ & $\mathbf{2 0 1 1}$ & Rata-rata \\
\hline Arsenal & $532,87 \%$ & $415,41 \%$ & $373,78 \%$ & $235,10 \%$ & $187,77 \%$ & $348,98 \%$ \\
Tottenham & $244,75 \%$ & $210,68 \%$ & $253,86 \%$ & $254,99 \%$ & $243,68 \%$ & $241,59 \%$ \\
Hotspurs & & & & & \\
Everton & $79,96 \%$ & $125,29 \%$ & $83,42 \%$ & $81,30 \%$ & $68,27 \%$ & $73,71 \%$ \\
\hline
\end{tabular}

Sumber: Data diolah, 2012

Dari Tabel 5, rata-rata total assets Arsenal adalah yang paling besar diantara yang lain, diikuti Tottenham Hotspurs dan terkecil adalah Everton, ini berarti ratarata dari total aset dibandingkan penjualan Arsenal selama lima tahun terakhir adalah yang paling tinggi dibandingkan dengan kedua klub lainnya. Hal ini juga dapat dilihat di Grafik 6. 
Dari Grafik 6, terlihat bahwa total assets ketiga klub memiliki kecenderungan menurun. Pada Arsenal hal ini terjadi karena total assets Arsenal terutama persediaan pengembangan properti mengalami penurunan, sedangkan penurunan total assets pada Everton terjadi karena kantor Goodison hampir berakhir masa manfaatnya. Pada Tottenham Hotspurs penurunan total assets terjadi karena peningkatan penjualannya lebih besar dari pada peningkatan total assetsnya.

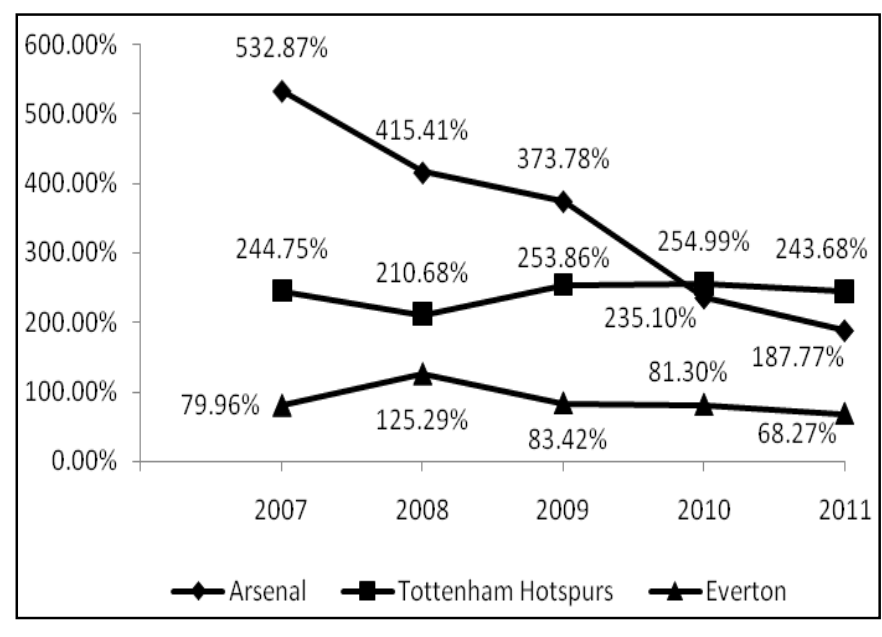

Grafik 6

Total Assets to Total Sales Ratio

Secara rata-rata dapat disimpulkan bahwa total assets Arsenal adalah yang paling baik di antara yang lain karena paling besar diantara yang lain yang berarti paling banyak menginvestasikan sales tahun sebelumnya untuk investasi di aset, terutama aset berwujudnya. Dengan investasi yang besar pada aset menunjukkan bahwa Arsenal dapat mengembangkan kegiatan operasinya dengan aset yang dimiliki. Sementara total assets Everton adalah yang paling buruk karena paling kecil diantara yang lain dan selalu berada di bawah 100 persen yang menunjukkan hanya sebagian dari sales tahun sebelumnya yang digunakan untuk investasi di aset. Dengan investasi pada aset yang sedikit menunjukkan bahwa peluang Everton untuk mengembangkan kegiatan operasinya kecil. Trend total assets ketiga klub samasama menunjukkan penurunan. Hal ini terjadi karena total assets ketiga klub dari tahun 2007 sampai 2011 selalu mengalami penurunan setiap tahunnya.

\section{Investment in Player Contracts}

Rasio ini adalah rasio yang mengukur seberapa besar penjualan periode tertentu yang digunakan untuk membeli dan membayar kontrak pemain. Bagi perusahaan yang mengkapitalisasi biaya kontrak pemain, biaya kontrak pemain diakui sebagai tambahan aset tidak berwujud untuk periode ini. Bagi perusahaan yang mengakui biaya kontrak pemain sebagai beban, biaya kontrak pemain ini adalah beban dalam laporan laba rugi. Berikut tabel investment in player contract tahun tertentu $\left(T F I N V_{t}\right)$ dan investment in player contract tahun sebelumnya $\left(T F I N V_{t-1}\right)$ dari Tottenham Hotspurs, Arsenal dan Everton untuk tahun 2007-2011. 
Berdasarkan Tabel 6, terlihat bahwa rata-rata $\operatorname{TFINV}_{t}$ danTFINV $V_{t-1}$ Tottenham Hotspurs adalah yang paling besar diantara yang lain, diikuti Everton dan yang terkecil adalah Arsenal. Ini berarti rata-rata dari pembayaran kontrak pemain dibandingkan penjualan Tottenham Hotspurs selama lima tahun terakhir adalah yang paling tinggi dibandingkan dengan kedua klub lainnya, yang berarti Tottenham Hotspurs paling banyak melakukan pembelian pemain dan pembayaran kontrak pemain. Hal ini juga dapat dilihat dalam Grafik 7.

Tabel 6

Investment in Player Contracts tahun tertentu (t) dan Investment In Player Contracts tahun sebelumnya $(t-1)$

\begin{tabular}{cccccccc}
\hline Nama Klub & Rasio & $\mathbf{2 0 0 7}$ & $\mathbf{2 0 0 8}$ & $\mathbf{2 0 0 9}$ & $\mathbf{2 0 1 0}$ & $\mathbf{2 0 1 1}$ & Rata-rata \\
\hline \multirow{2}{*}{ Arsenal } & TFINV & $10,89 \%$ & $12,57 \%$ & $11,30 \%$ & $7,88 \%$ & $11,17 \%$ & $10,76 \%$ \\
& TFINVt $_{-1}$ & $15,94 \%$ & $13,95 \%$ & $15,88 \%$ & $9,56 \%$ & $7,52 \%$ & $12,57 \%$ \\
Tottenham & TFINV $_{t}$ & $47,24 \%$ & $75,97 \%$ & $28,32 \%$ & $15,44 \%$ & $4,89 \%$ & $34,37 \%$ \\
Hotspurs & TFINVt $_{-1}$ & $65,69 \%$ & $84,59 \%$ & $27,88 \%$ & $16,37 \%$ & $6,68 \%$ & $40,24 \%$ \\
& TFINV & $37,44 \%$ & $22,47 \%$ & $25,10 \%$ & $1,90 \%$ & $9,75 \%$ & $19,33 \%$ \\
Everton & TFINVt & $33,12 \%$ & $33,07 \%$ & $26,44 \%$ & $1,88 \%$ & $10,12 \%$ & $20,92 \%$ \\
\hline
\end{tabular}

Sumber: Data diolah, 2012

Dari Grafik 7 terlihat bahwa $T F I N V_{t}$ dan $T F I N V_{t-1}$ Tottenham Hotspurs dan Everton berfluktuasi dan cenderung mengalami penurunan, sementara $\operatorname{TFINV}_{t}$ dan $T_{F I N V_{t-1}}$ Arsenal cenderung stabil. Sebelum Tottenham Hotspurs mengalami penurunan TFINV $_{t}$ dan TFINV $V_{t-1}$ di tahun 2009, TFINV $V_{t}$ dan TFINV $V_{t-1}$ Tottenham Hotspurs pada tahun 2008 meningkat karena Tottenham Hotspurs melakukan banyak pembelian pemain pada tahun 2008. Sementara penurunan $T F I N V_{t}$ dan $T F I N V_{t-1}$ Tottenham Hotspurs dari tahun 2009 hingga 2011 disebabkan karena Tottenham Hotspurs dari tahun 2009-2011 semakin sedikit melakukan pembelian pemain. Penurunan $T F I N V_{t}$ dan $T F I N V_{t-1}$ Everton juga terjadi karena Everton semakin jarang melakukan pembelian pemain.

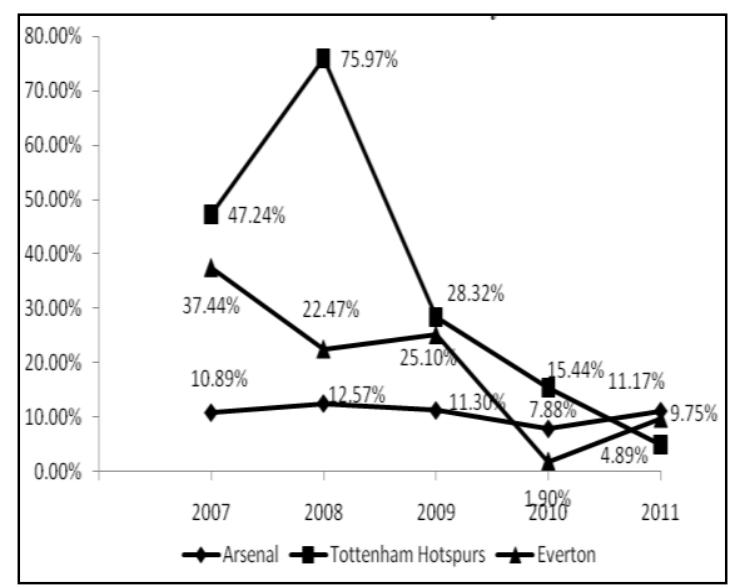

tahun $\mathbf{t}$

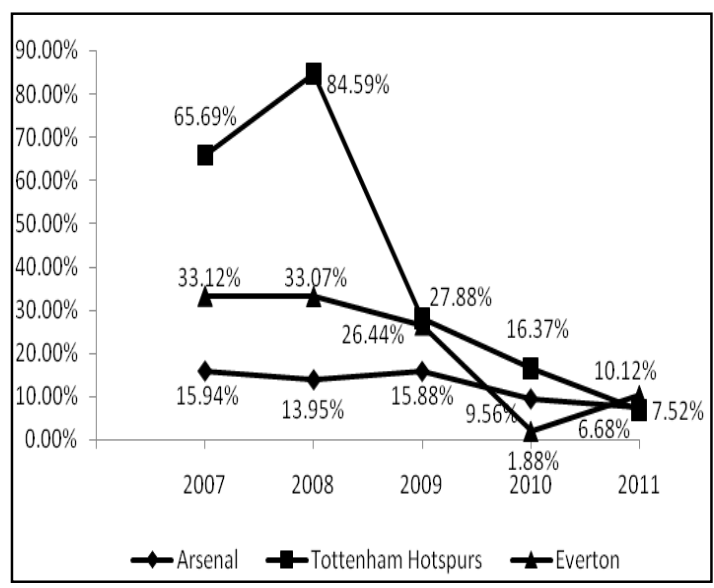

tahun t-1

Grafik 7

Investment In Player Contracts Tahun Tertentu (t) dan Investment in Player Contracts Tahun Sebelumnya (t-1) 
Secara rata-rata dapat disimpulkan bahwa rasio $T F I N V_{t}$ dan $T F I N V_{t-1}$ Arsenal adalah yang paling stabil dan rata-ratanya paling rendah yang berarti Arsenal paling jarang melakukan pembelian pemain dan pembayaran kontrak pemain. Sedangkan, Tottenham Hotspurs rata-ratanya paling tinggi, yang berarti diantara dua klub lainnya Tottenham Hotspurs paling banyak melakukan pembelian pemain dan pembayaran kontrak pemain.

\section{Cash Received From Selling Player Contract}

Rasio ini adalah rasio yang menunjukkan seberapa besar penjualan pada periode tertentu yang diperoleh dari penjualan pemain. Bagi perusahaan yang mengkapitalisasi biaya kontrak pemain, pendapatan dari penjualan pemain ini dilaporkan dalam laporan arus kas. Bagi perusahaan yang mengakui biaya kontrak pemain sebagai beban, pendapatan dari penjualan pemain ini ini dilaporkan dalam laporan laba rugi. Berikut tabel cash received from selling player contract tahun tertentu (TFREC $C_{t}$ ) dan cash received from selling player contract tahun sebelumnya (TFREC $C_{t-1}$ ) dari Tottenham Hotspurs, Arsenal dan Everton untuk tahun 2007-2011.

Berdasarkan Tabel 7, terlihat bahwa rata-rata TFREC $C_{t}$ dan TFREC $C_{t-1}$ Tottenham Hotspurs adalah yang paling besar di antara yang lain, diikuti Everton, yang terkecil adalah Arsenal. Ini berarti rata-rata dari current cash received from selling player contract dibandingkan penjualan Tottenham Hotspurs selama lima tahun terakhir adalah yang paling tinggi dibandingkan dengan kedua klub lainnya, yang berarti Tottenham Hotspurs paling banyak menerima pendapatan dari penjualan pemain. Hal ini juga dapat dilihat dalam Grafik 8.

Tabel 7

Cash Received from Selling Player Contract tahun tertentu (t) dan Cash Received from Selling Player Contract tahun sebelumnya $(\mathrm{t}-1)$

\begin{tabular}{cccccccc}
\hline Nama Klub & Rasio & $\mathbf{2 0 0 7}$ & $\mathbf{2 0 0 8}$ & $\mathbf{2 0 0 9}$ & $\mathbf{2 0 1 0}$ & $\mathbf{2 0 1 1}$ & Rata-rata \\
\hline \multirow{2}{*}{ Arsenal } & TFREC & $6,91 \%$ & $14,37 \%$ & $7,36 \%$ & $12,07 \%$ & $10,57 \%$ & $10,26 \%$ \\
& TFREC $_{t-1}$ & $10,11 \%$ & $15,95 \%$ & $10,34 \%$ & $14,63 \%$ & $7,12 \%$ & $11,63 \%$ \\
Tottenham & TFREC $_{t}$ & $14,31 \%$ & $59,02 \%$ & $29,20 \%$ & $0,83 \%$ & $21,41 \%$ & $24,95 \%$ \\
Hotspurs & TFREC $_{t-1}$ & $19,89 \%$ & $65,72 \%$ & $28,75 \%$ & $0,88 \%$ & $29,21 \%$ & $28,89 \%$ \\
& TFREC & $17,02 \%$ & $13,88 \%$ & $28,62 \%$ & $4,05 \%$ & $24,99 \%$ & $17,71 \%$ \\
Everton & TFREC & $15,05 \%$ & $20,42 \%$ & $30,14 \%$ & $4,02 \%$ & $25,92 \%$ & $19,11 \%$ \\
\hline
\end{tabular}

Sumber: Data diolah, 2012

Berdasarkan Grafik 8, TFREC $C_{t}$ dan $T F R E C_{t-1}$ Arsenal cenderung stabil, sementara TFREC $C_{t}$ dan TFREC $C_{t-1}$ Tottenham Hotspurs dan Everton cenderung berfluktuasi dan mengalami penurunan. Kenaikkan $T F R E C_{t}$ dan $T F R E C_{t-1}$ Tottenham Hotspurs yang signifikan pada tahun 2008 terjadi karena pada tahun tersebut selain Tottenham Hotspurs banyak melakukan pembelian pemain, Tottenham Hotspurs juga melakukan penjualan pemain yang banyak. Sementara penurunan TFREC $_{t}$ dan TFREC $_{t-1}$ Tottenham Hotspurs pada tahun 2009 terjadi karena pada tahun 2009 
Tottenham Hotspurs tidak melakukan penjualan pemain sebanyak di tahun 2008 . Penurunan Everton juga terjadi karena Everton jarang melakukan penjualan pemain.
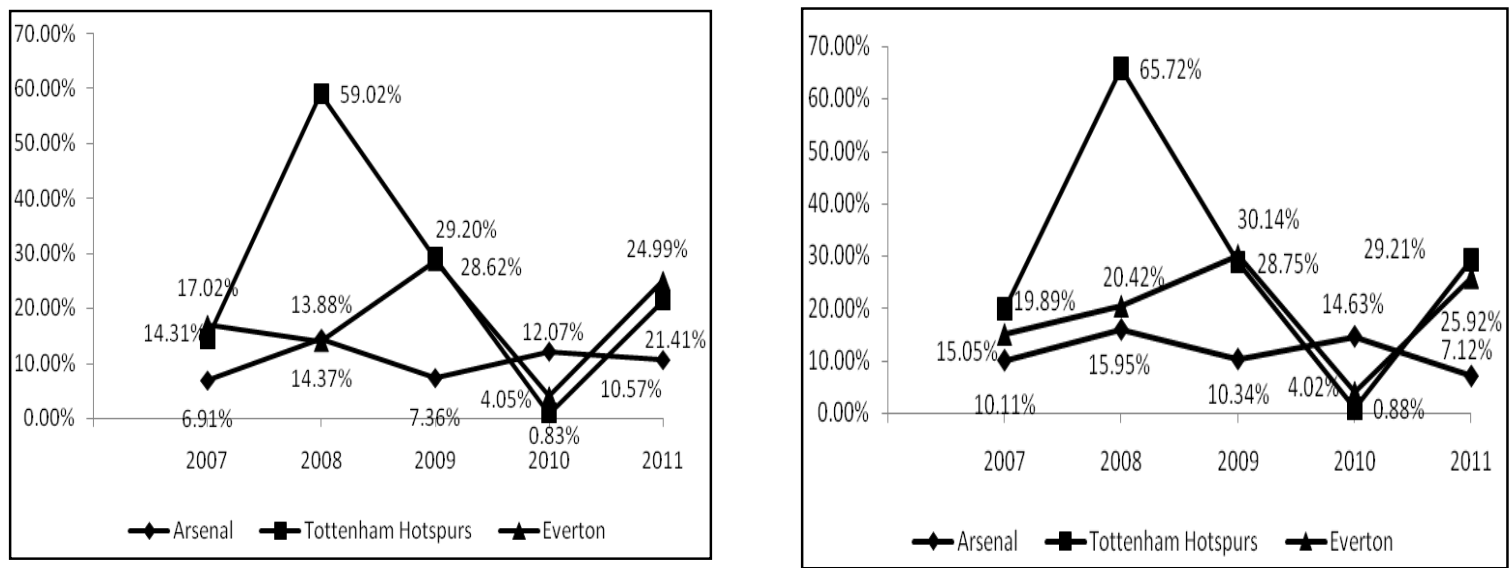

Grafik 8

Cash Received from Selling Player Contract tahun tertentu (t) dan Cash Received from Selling Player Contract tahun sebelumnya (t-1)

Secara rata-rata dapat disimpulkan bahwa rasio $T F R E C_{t}$ dan $T_{F R E C_{t-1}}$ Tottenham Hotspurs yang paling besar, diikuti Everton dan yang terkecil adalah Arsenal. TFREC $C_{t}$ dan TFREC $C_{t-1}$ Tottenham Hotspurs paling besar yang berarti paling banyak melakukan penjualan pemain. Sedangkan TFREC $C_{t}$ dan TFREC $C_{t-1}$ Arsenal paling kecil, yang berarti paling jarang melakukan penjualan pemain, sehingga $T_{F R E C_{t}}$ dan TFREC $_{t-1}$ Arsenal paling stabil diantara yang lain.

\section{Net Investment In Player Contracts}

Rasio ini adalah rasio yang digunakan untuk mengetahui selisih antara penjualan dan pembelian pemain.Berikut tabel net investment in player contracts (NINV) dari Tottenham Hotspurs, Arsenal dan Everton untuk tahun 2007-2011:

Dari Tabel 8, rata-rata NINV Tottenham Hotspurs yang terbesar, diikuti Everton dan yang terkecil adalah Arsenal, ini berarti rata-rata dari selisih penjualan dan pembelian pemain dibandingkan dengan penjualan Tottenham Hotspurs selama lima tahun terakhir adalah yang paling tinggi dibandingkan dengan kedua klub lainnya, yang berarti Tottenham Hotspurs paling banyak melakukan investasi bersih dalam kontrak pemain. Hal ini juga dapat dilihat dalam Grafik 9.

Dari Grafik 9, terlihat bahwa NINV Everton dan Tottenham Hotspurs berfluktuasi tetapi cenderung mengalami penurunan, sementara NINV Arsenal cenderung stabil. Penurunan NINV Tottenham Hotspurs pada tahun 2009 terjadi karena pada tahun tersebut Tottenham Hotspurs jarang melakukan penjualan dan pembelian pemain. Sementara penurunan NINV Tottenham Hotspurs yang signifikan pada tahun 2011 terjadi karena pada tahun 2011, Tottenham melakukan lebih banyak penjualan pemain dari pada pembelian pemain. Penurunan NINV Everton terjadi 
karena Everton semakin jarang melakukan pembelian dan penjualan pemain. Sedangkan penurunan NINV pada Arsenal tidak signifikan karena Arsenal tidak terlalu banyak melakukan jual dan beli pemain sehingga NINV Arsenal cenderung lebih stabil.

Tabel 8

Net Investment in Player Contracts

\begin{tabular}{ccccccc}
\hline Nama Klub & $\mathbf{2 0 0 7}$ & $\mathbf{2 0 0 8}$ & $\mathbf{2 0 0 9}$ & $\mathbf{2 0 1 0}$ & $\mathbf{2 0 1 1}$ & Rata-rata \\
\hline Arsenal & $5,84 \%$ & $-2,00 \%$ & $5,53 \%$ & $-5,08 \%$ & $0,40 \%$ & $0,94 \%$ \\
Tottenham & $45,79 \%$ & $18,87 \%$ & $-0,87 \%$ & $15,49 \%$ & $-22,53 \%$ & $11,35 \%$ \\
Hotspurs & & $12,64 \%$ & $-3,70 \%$ & $-2,13 \%$ & $-15,81 \%$ & $1,81 \%$ \\
Everton & $18,07 \%$ & $1,64 \%$ &
\end{tabular}

Sumber: Data diolah, 2012

Secara rata-rata dapat disimpulkan bahwa, rasio NINV Arsenal adalah yang paling paling kecil. Rasio NINV Arsenal yang kecil selain karena penjualannya besar, juga disebabkan oleh selisih penjualan dan pembelian pemain yang dilakukan Arsenal lebih kecil dari pada dua klub lainnya, yang berarti Arsenal selalu mengimbangi pembelian pemain dengan penjualan. NINV Tottenham Hotspurs paling tidak stabil dan paling besar. Rasio NINV Tottenham Hotspurs yang besar disebabkan selisih pembelian dan penjualan pemainnya besar, yang berarti Tottenham Hotspurs tidak mengimbangi pembelian pemain dengan penjualan.

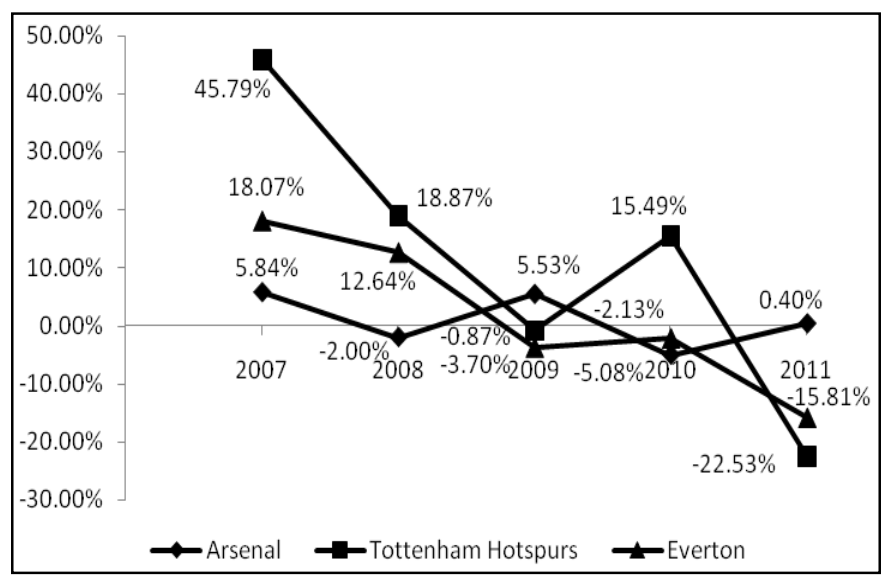

Grafik 9

\section{Adjusted Leverage}

Net Investment In Player Contracts

Rasio ini adalah rasio yang membagi jumlah kewajiban dengan total aset (setelah kapitalisasi kontrak pemain dikeluarkan). Rasio ini menunjukkan seberapa besar aset dapat dibiayai dengan utangnya. Berikut tabel adjusted leverage dari Tottenham Hotspurs, Arsenal dan Everton untuk tahun 2007-2011. 
Tabel 9

Adjusted Leverage

\begin{tabular}{lcccccc}
\hline $\begin{array}{c}\text { Nama } \\
\text { Klub }\end{array}$ & $\mathbf{2 0 0 7}$ & $\mathbf{2 0 0 8}$ & $\mathbf{2 0 0 9}$ & $\mathbf{2 0 1 0}$ & $\mathbf{2 0 1 1}$ & $\begin{array}{c}\text { Rata- } \\
\text { rata }\end{array}$ \\
\hline Arsenal & $81,76 \%$ & $78,77 \%$ & $76,68 \%$ & $65,34 \%$ & $62,43 \%$ & $73 \%$ \\
Tottenham & $74,84 \%$ & $80,38 \%$ & $78,70 \%$ & $75,53 \%$ & $72,09 \%$ & $76,31 \%$ \\
Hotspurs & $142,57 \%$ & $130,68 \%$ & $142,28 \%$ & $145,97 \%$ & $165,18 \%$ & $145,34 \%$ \\
Everton & & & & &
\end{tabular}

Sumber: Data diolah, 2012

Dari Tabel 9, rata-rata adjusted leverage Everton adalah yang paling besar, diikuti Tottenham Hotspurs dan yang terkecil adalah Arsenal, ini berarti rata-rata dari total kewajiban dibandingkan total aset Everton selama lima tahun terakhir adalah yang paling tinggi dibandingkan dengan kedua klub yang lainnya, yang berarti Everton paling berisiko karena total aset yang dimiliki tidak dapat menutup kewajibannya. Hal ini juga dapat dilihat dalam Grafik 10.

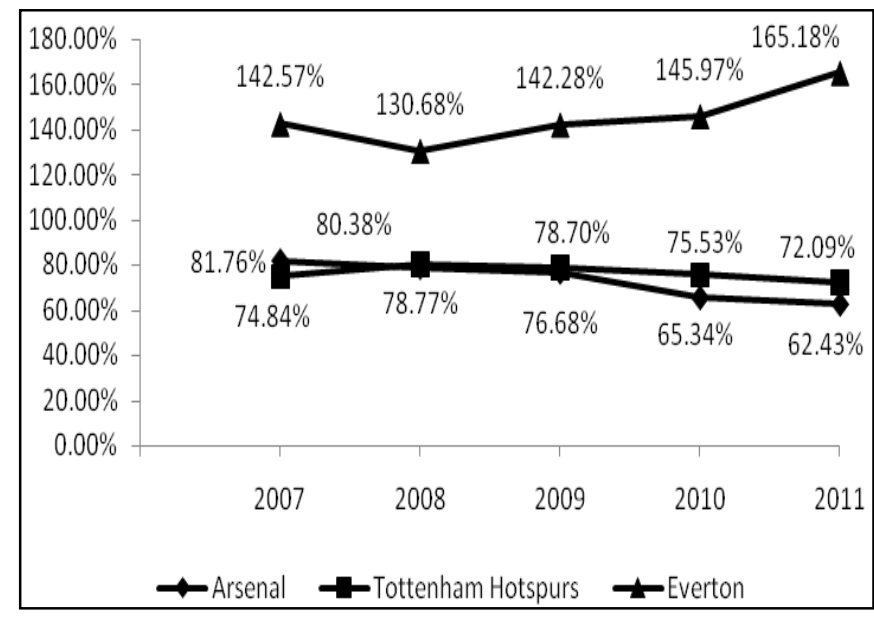

Grafik 10

Adjusted Leverage

Berdasarkan Grafik 10, adjusted leverage Arsenal dan Tottenham Hotspurs cenderung stabil, walaupun sejak tahun 2009 cenderung mengalami sedikit penurunan. Sedangkan adjusted leverage Everton cenderung mengalami kenaikkan. Kenaikkan adjusted leverage pada Everton terjadi karena penurunan total aset Everton yaitu kantornya yang bernama Goodison hampir berakhir masa manfaatnya. Sedikit penurunan adjusted leverage pada Arsenal terjadi karena penurunan kewajibannya, yaitu pendapatan akrual diterima dimuka lebih besar dari pada penurunan total asetnya, sedangkan sedikit penurunan adjusted leverage pada Tottenham Hotspurs terjadi karena penurunan saham preferen Convertible Redeemable Preference Sharesnya.

Secara keseluruhan dapat disimpulkan bahwa rasio adjusted leverage Arsenal adalah yang paling baik karena paling rendah dibandingkan dua klub lainnya, yang 
berarti Arsenal paling mampu menutupi kewajibannya dengan asetnya. Sementara adjusted leverage Everton adalah yang paling buruk karena paling besar dan selalu diatas $100 \%$ yang berarti risiko Everton paling besar karena kewajiban Everton selalu lebih besar dari pada asetnya.

\section{Contract Amortization Rate}

Rasio ini adalah rasio yang membagi amortisasi kontrak pemain ditambah kontrak write-off, dengan biaya kontrak pemain. Berikut tabel contract amortization rate dari Tottenham Hotspurs, Arsenal dan Everton untuk tahun 2007-2011:

Tabel 10

Contract Amortization Rate

\begin{tabular}{ccccccc}
\hline Nama Klub & $\mathbf{2 0 0 7}$ & $\mathbf{2 0 0 8}$ & $\mathbf{2 0 0 9}$ & $\mathbf{2 0 1 0}$ & $\mathbf{2 0 1 1}$ & Rata-rata \\
\hline Arsenal & $15,37 \%$ & $19,13 \%$ & $18,16 \%$ & $17,39 \%$ & $15,66 \%$ & $17,14 \%$ \\
Tottenham & $17,54 \%$ & $28,95 \%$ & $18,92 \%$ & $19,79 \%$ & $18,46 \%$ & $20,73 \%$ \\
$\begin{array}{c}\text { Hotspurs } \\
\text { Everton }\end{array}$ & $17,14 \%$ & $17,72 \%$ & $17,13 \%$ & $18,77 \%$ & $18,07 \%$ & $17,77 \%$ \\
\hline
\end{tabular}

Sumber: Data diolah, 2012

Dari Tabel 10, rata-rata contract amortization rate Tottenham Hotspurs adalah yang paling besar, diikuti Everton dan yang terkecil adalah Arsenal, ini berarti rata-rata dari amortisasi kontrak pemain dibandingkan biaya kontrak pemain Tottenham Hotspurs selama lima tahun terakhir adalah yang paling tinggi dibandingkan dengan kedua klub yang lainnya, yang artinya Tottenham Hotspurs paling banyak mengalami penyusutan kontrak pemain terkait dengan jumlah pembelian dan penjualan pemainnya yang paling besar diantara yang lain. Hal ini juga dapat dilihat dalam Grafik 11.

Dari Grafik 11, contract amortization rate ketiga klub cenderung stabil, kecuali Tottenham Hotspurs mengalami kenaikkan pada tahun 2008. Kenaikkan Tottenham Hotspurs pada tahun 2008 karena pada tahun tersebut Tottenham Hotspurs banyak melakukan pembelian dan penjualan pemain. Contract amortization rate Everton cenderung stabil karena beban penyusutan dan biaya kontrak pemain Everton tidak berubah banyak dari tahun 2007 sampai 2011. Sementara contract amortization rate Arsenal stabil karena beban penyusutan dan biaya kontrak pemain Arsenal yang stabil, sesuai dengan tipe Arsenal yang jarang melakukan pembelian dan penjualan pemain.

Secara keseluruhan dapat disimpulkan bahwa, rasio contract amortization rate Arsenal adalah yang paling kecil diantara yang lain, diikuti Everton dan terbesar adalah Tottenham Hotspurs. Contract amortization rate Arsenal adalah paling kecil diantara dua klub lainnya karena berkaitan dengan jumlah investment in player contracts, cash received from player contract dan net investment in player contracts Arsenal yang kecil, sesuai dengan gaya Arsenal yang tidak suka melakukan jual-beli pemain. Sedangkan contract amortization rate Tottenham Hotspurs adalah yang 
paling besar diantara yang lain karena terkait dengan jumlah investment in player contracts, cash received from player contract dan net investment in player contracts Tottenham Hotspurs yang besar.

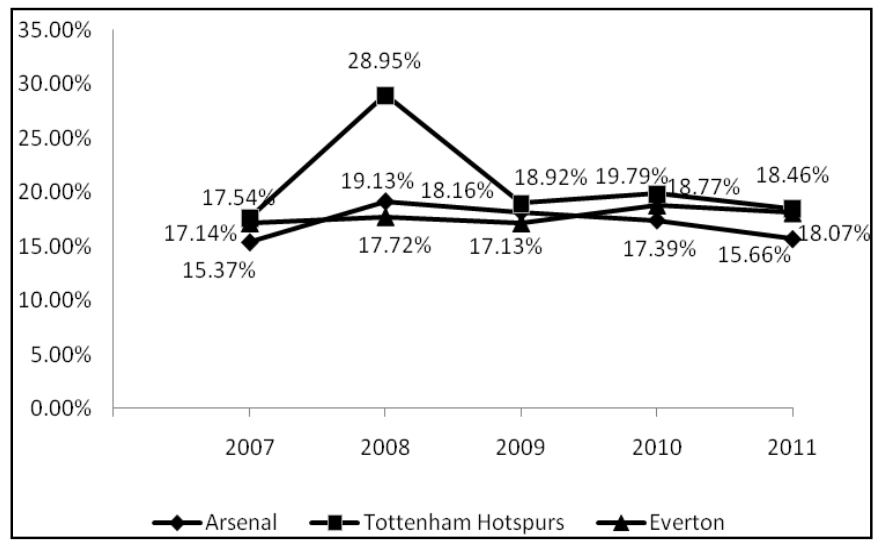

Grafik 11

\section{Intangible Intensity}

Contract Amortization Rate

Rasio ini adalah rasio yang membagi biaya kontrak pemain dikurangi akumulasi amortisasi dengan total aset. Rasio ini untuk melihat seberapa besar proporsi kontrak pemain sepak bola dalam total aset. Berikut tabel intangible intensity dari Tottenham Hotspurs, Arsenal dan Everton untuk tahun 2007-2011.

Tabel 11

Intangible Intensity

\begin{tabular}{ccccccc}
\hline Nama Klub & $\mathbf{2 0 0 7}$ & $\mathbf{2 0 0 8}$ & $\mathbf{2 0 0 9}$ & $\mathbf{2 0 1 0}$ & $\mathbf{2 0 1 1}$ & Rata-rata \\
\hline Arsenal & $8,84 \%$ & $6,67 \%$ & $8,21 \%$ & $8,23 \%$ & $7,81 \%$ & $7,95 \%$ \\
Tottenham & $40,68 \%$ & $28,74 \%$ & $44,07 \%$ & $40,14 \%$ & $34,67 \%$ & $37,66 \%$ \\
Hotspurs & $56,99 \%$ & $61,22 \%$ & $62,40 \%$ & $69,89 \%$ & $61,74 \%$ & $62,45 \%$ \\
Everton & & & & &
\end{tabular}

Sumber: Data diolah, 2012

Dari Tabel 11, rata-rata intangible intensity Everton adalah yang paling besar, diikuti Tottenham Hotspurs dan yang terkecil adalah Arsenal, ini berarti rata-rata dari selisih biaya kontrak pemain dengan akumulasi kontrak dibandingkan dengan total aset Everton selama lima tahun terakhir adalah yang paling tinggi dibandingkan dengan kedua klub yang lainnya, yang artinya Everton lebih memilih untuk mengontrak pemain sepak bola sebagai aset dibandingkan dua klub lainnya. Hal ini juga dapat dilihat dalam Grafik 12.

Dari Grafik 12, intangible intensity Tottenham Hotspurs dan Everton cenderung mengalami penurunan, sementara intangible intensity Arsenal cenderung stabil. Penurunan intangible intensity pada Tottenham Hotspurs dan Everton terjadi karena tambahan biaya kontraknya dari tahun ke tahun mengalami penurunan, sedangkan akumulasi penyusutan dari kedua klub meningkat. Akumulasi penyusutan 
yang meningkat tidak lepas dari semakin besarnya penyusutan dari tahun ke tahun. Menurunnya intangible intensity menunjukkan semakin kecilnya proporsi kontrak pemain sepak bola di dalam aset. Sementara intangible intensity Arsenal cenderung stabil karena tipe Arsenal yang tidak suka melakukan pembelian dan penjualan pemain.

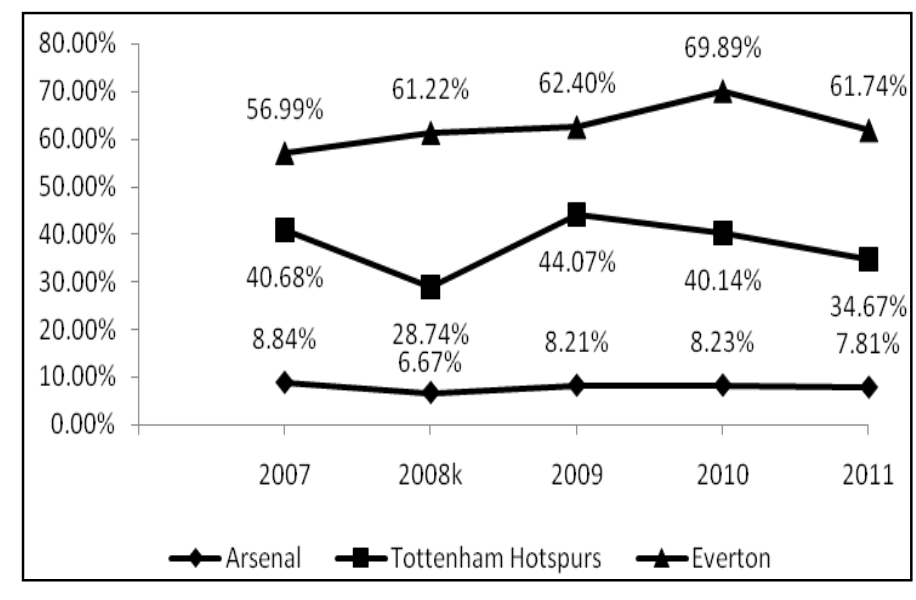

Grafik 12

Intangible Intensity

Secara rata-rata dapat disimpulkan bahwa rasio intangible intensity Arsenal adalah yang paling baik karena paling kecil, yang berarti dibandingkan klub yang lain, hanya sebagian kecil dari total aset Arsenal yang berasal dari kontrak pemain. Proporsi kontrak pemain sepak bola yang kecil dalam total aset menunjukkan aset yang dimiliki lebih beragam, sehingga tidak hanya bergantung pada kontrak pemain sepak bola. Sementara intangible intensity Everton adalah yang paling buruk karena paling besar, yang berarti sebagian besar total asetnya adalah kontrak pemain. Proporsi kontrak pemain sepak bola yang besar dalam total aset menunjukkan aset yang dimiliki kurang beragam dan bergantung pada kontrak pemain sepak bola, sehingga akan sangat berisiko jika kontrak pemain sepak bola kurang baik.

\section{Current Ratio}

Rasio ini menunjukkan seberapa banyak aset lancar yang tersedia untuk menutupi kewajiban jangka pendek yang segera jatuh tempo. Rasio lancar yang lebih aman adalah jika berada di atas 1 atau di atas 100 persen. Artinya aset lancar harus jauh di atas jumlah utang lancar. Berikut tabel current ratio dari Tottenham Hotspurs, Arsenal dan Everton untuk tahun 2007-2011.

Tabel 12

Current Ratio

\begin{tabular}{ccccccc}
\hline Nama Klub & $\mathbf{2 0 0 7}$ & $\mathbf{2 0 0 8}$ & $\mathbf{2 0 0 9}$ & $\mathbf{2 0 1 0}$ & $\mathbf{2 0 1 1}$ & Rata-rata \\
\hline Arsenal & $140,82 \%$ & $98,35 \%$ & $103,11 \%$ & $155,30 \%$ & $171,20 \%$ & $133,76 \%$ \\
Tottenham Hotspurs & $82,23 \%$ & $88,72 \%$ & $57,01 \%$ & $43,52 \%$ & $34,03 \%$ & $61,10 \%$ \\
Everton & $20,62 \%$ & $29,64 \%$ & $27,98 \%$ & $21,91 \%$ & $24,77 \%$ & $24,99 \%$ \\
\hline
\end{tabular}

Sumber: Data diolah, 2012 
Dari Tabel 12, rata-rata current ratio yang paling besar adalah Arsenal, diikuti Tottenham Hotspurs dan yang terkecil adalah Everton, ini berarti rata-rata dari aset lancar dibandingkan kewajiban lancar Arsenal selama lima tahun terakhir adalah yang paling tinggi dibandingkan dengan kedua klub lainnya, yang artinya Arsenal paling mampu untuk membayar kewajiban lancarnya dengan aset lancar yang Arsenal miliki. Hal ini juga dapat dilihat di Grafik 13.

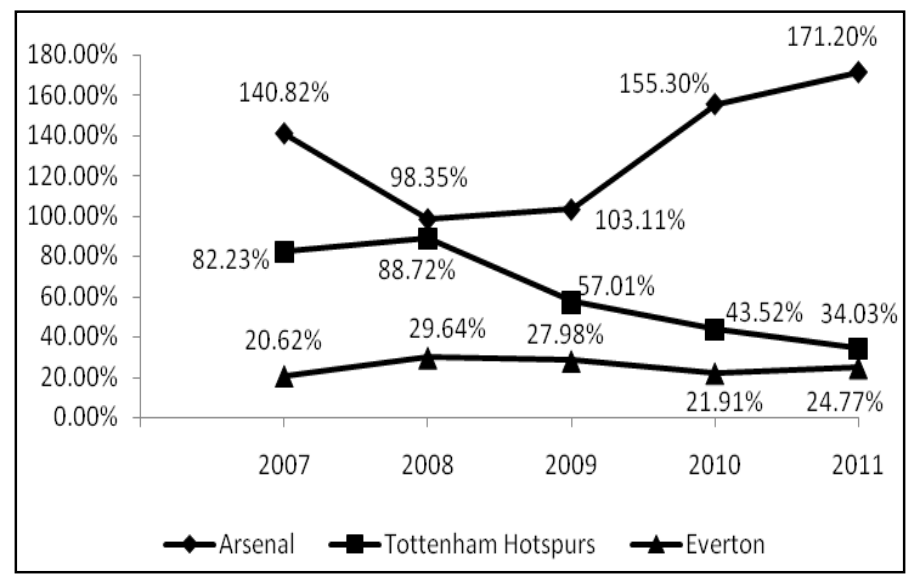

\section{Grafik 13 \\ Current Ratio}

Berdasarkan Grafik 13, current ratio dari Tottenham Hotspurs cenderung mengalami penurunan, sedangkan current ratio dari Arsenal cenderung mengalami kenaikkan dan Everton cenderung mengalami stabil. Penurunan current ratio dari Tottenham Hotspurs terjadi karena kewajiban lancarnya selalu lebih besar dari aset lancarnya dan pada tahun 2009, aset lancar dari Tottenham Hotspurs mengalami penurunan sedangkan kewajiban lancarnya mengalami peningkatan. Kenaikkan current ratio pada Arsenal terjadi karena sejak tahun 2009 aset lancarnya selalu lebih besar dari pada kewajiban lancarnya dan penurunan kewajiban lancarnya lebih besar dari pada penurunan aset lancarnya. Sedangkan Everton cenderung stabil karena dari tahun 2007-2011 tidak banyak mengalami perubahan dalam aset lancar dan kewajiban lancarnya.

Secara rata-rata dapat disimpulkan bahwa, rasio current ratio Arsenal adalah yang paling baik karena paling besar dan selalu berada di atas 100 persen. Ini berarti aset lancarnya selalu lebih besar dari kewajiban lancarnya yang artinya diantara yang lain Arsenal paling mampu untuk menutupi kewajiban jangka pendek yang segera jatuh tempo dengan aset lancarnya. Sedangkan current ratio Everton adalah yang paling buruk karena paling kecil yang berarti paling tidak lancar dibandingkan kedua klub yang lain dan paling berisiko pailit karena tidak dapat membayar kewajibannya. 


\section{Assets Turnover}

Rasio ini mengukur perputaran semua aset yang dimiliki perusahaan dan mengukur berapa jumlah penjualan yang diperoleh dari setiap rupiah aset. Berikut tabel assets turnover tahun 2007- 2011 dari Tottenham Hotspurs, Arsenal dan Everton.

Dari tabel di atas, rata-rata asset turnover Everton adalah yang paling besar, diikuti Tottenham Hotspurs dan terkecil adalah Arsenal, ini berarti rata-rata penjualan dibandingkan dengan total assets Everton selama lima tahun terakhir adalah yang paling tinggi dibandingkan dengan kedua klub lainnya, yang artinya paling banyak menghasilkan penjualan dengan aset yang dimiliki. Hal ini juga dapat dilihat dalam Grafik 14.

Tabel 13

Asset Turnover

\begin{tabular}{lrrrccc}
\hline Nama Klub & $\mathbf{2 0 0 7}$ & $\mathbf{2 0 0 8}$ & $\mathbf{2 0 0 9}$ & $\mathbf{2 0 1 0}$ & $\mathbf{2 0 1 1}$ & Rata-rata \\
\hline Arsenal & $27,46 \%$ & $26,72 \%$ & $37,60 \%$ & $51,56 \%$ & $35,85 \%$ & $35,84 \%$ \\
Tottenham & $56,81 \%$ & $52,85 \%$ & $38,78 \%$ & $41,58 \%$ & $55,99 \%$ & $49,20 \%$ \\
Hotspurs & & & $126,24 \%$ & $122,08 \%$ & $151,94 \%$ & $125,66 \%$ \\
Everton & $110,62 \%$ & $117,44 \%$ & & &
\end{tabular}

Sumber: Data diolah, 2012

Dari Grafik 14, assets turnover ketiga klub berfluktuasi, tetapi Everton dan Tottenham Hotspurs cenderung mengalami kenaikkan, sedangkan Arsenal cenderung stabil. Kenaikkan asset turnover Everton terjadi karena pada tahun 2007 sampai 2011 total assets Everton mengalami penurunan akibat kantor Goodison yang masa manfaatnya hampir habis dan proposi kontrak pemain sepak bola dalam asetnya mengalami penurunan. Sedangkan assets turnover Tottenham Hotspurs mengalami kenaikkan karena peningkatan penjualan Tottenham Hotspurs lebih besar dari pada peningkatan total assetsnya. Sedangkan asset turnover pada Arsenal cenderung stabil kecuali tahun 2009 dan 2010 mengalami kenaikkan karena pada dua tahun tersebut, Arsenal mengalami kenaikkan penjualan sementara total asetnya mengalami penurunan.

Secara rata-rata dapat disimpulkan bahwa rasio asset turnover Everton adalah yang paling baik karena dibandingkan dua klub lainnya, jumlahnya paling besar, yang berarti perputaran aset Everton adalah yang paling lancar dan penjualan yang diperoleh dari setiap rupiah aset Everton paling besar diantara yang lain. Sementara assets turnover yang paling buruk adalah Arsenal karena jumlahnya paling kecil yang berarti perputaran asetnya paling lambat diantara dua klub lainnya. 


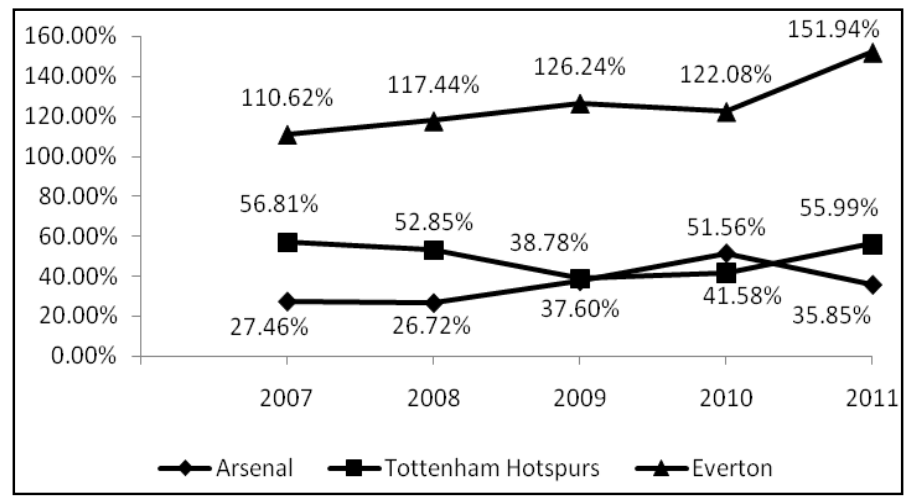

Grafik 14

Asset Turnover

\section{Rate of Return to Assets}

Rasio yang menunjukkan hasil dari investasi atau aset yang dipakai perusahaan. Semakin besar rasio ini semakin baik perusahaan dalam menggunakan aset dan investasinya untuk menghasilkan laba. Berikut tabel rate of return to assets tahun 2007-2011 dari Tottenham Hotspurs, Arsenal dan Everton:

Tabel 14

Rate of Return to Assets

\begin{tabular}{lcccccc}
\hline \multicolumn{1}{c}{ Nama Klub } & $\mathbf{2 0 0 7}$ & $\mathbf{2 0 0 8}$ & $\mathbf{2 0 0 9}$ & $\mathbf{2 0 1 0}$ & $\mathbf{2 0 1 1}$ & Rata-rata \\
\hline Arsenal & $0,39 \%$ & $3,08 \%$ & $4,23 \%$ & $8,28 \%$ & $1,77 \%$ & $3,55 \%$ \\
Tottenham & $10,56 \%$ & $0,45 \%$ & $7,95 \%$ & $-2,31 \%$ & $0,23 \%$ & $3,38 \%$ \\
Hotspurs & $-20,28 \%$ & $0,04 \%$ & $-10,97 \%$ & $-4,78 \%$ & $-10,03 \%$ & $-9,20 \%$ \\
Everton & & & & & &
\end{tabular}

Sumber: Data diolah, 2012

Dari Tabel 14, rata-rata rate of return to assets Arsenal adalah yang paling besar diantara yang lain, diikuti Tottenham Hotspurs dan terkecil adalah Everton, ini berarti rata-rata laba bersih dibandingkan dengan total assets Arsenal selama lima tahun terakhir adalah yang paling tinggi dibandingkan dengan kedua klub lainnya, yang artinya Arsenal paling baik dalam menggunakan aset dan investasinya untuk menghasilkan laba. Hal ini juga dapat dilihat di Grafik 15.

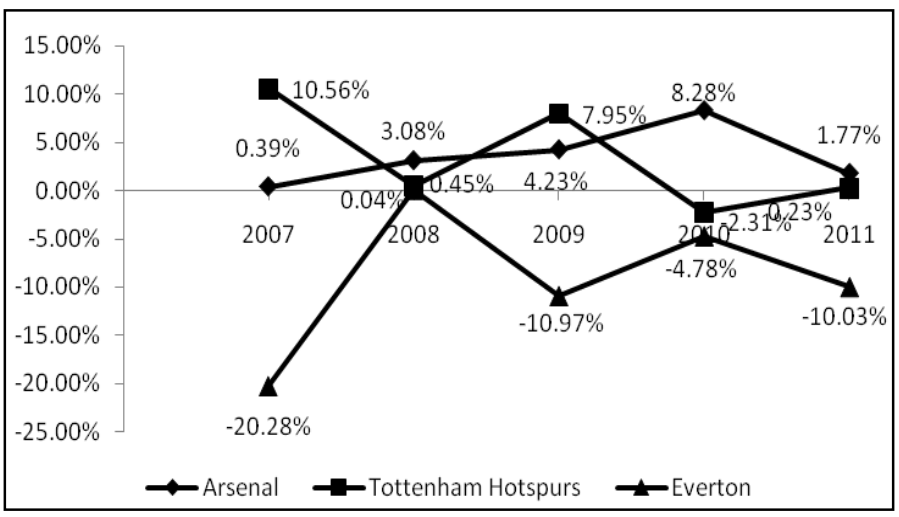

Grafik 15

Rate of Return to Assets 
Dari Grafik 15 di atas, rate of return to assets ketiga klub berfluktuasi. Arsenal walaupun rate of return to assetsnya berfluktuasi tetapi sempat mengalami kenaikkan hingga tahun 2010, sebelum rate of return to assets Arsenal mengalami penurunan pada tahun 2011. Penurunan rate of return to assets Arsenal tahun 2011 terjadi karena pada tahun 2011 Arsenal membayar pajak yang lebih besar, sehingga laba bersih dari Arsenal mengalami penurunan yang lebih besar dari pada penurunan total assets.

Grafik 15 juga menunjukkan bahwa Everton selalu memiliki rate of return to assets yang negatif yang berarti walaupun asset turnovernya besar tetapi tidak menghasilkan laba yang besar, kecuali pada tahun 2008 sempat menjadi positif dan mengalami kenaikkan besar karena pada tahun tersebut Everton mengalami laba bersih. Sementara Tottenham Hotspurs hampir selalu memiliki rate of return to assets yang positif kecuali tahun 2010 Tottenham Hotspurs mengalami kerugian bersih karena keuntungan dari pelepasan intangible assetsnya termasuk penjualan pemain tidak dapat menutupi kerugian operasinya.

Secara rata-rata dapat disimpulkan bahwa rasio rate of return to assets Arsenal adalah yang paling baik diantara yang lain, diikuti Tottenham Hotspurs dan terburuk adalah Everton. Rate of return to assets Arsenal paling baik karena paling besar diantara yang lain yang berarti Arsenal paling mampu dalam menggunakan aset dan investasinya untuk menghasilkan laba dibandingkan dua klub lainnya. Selain itu, rate of return to assets Arsenal selalu menujukkan angka yang positif, yang berarti Arsenal selalu mampu untuk memperoleh laba bersih sepanjang 20072011, walaupun asset turnovernya kecil. Sementara Rate of Return to Assets Everton yang paling buruk karena paling kecil dan hampir selalu mengalami kerugian bersih.

\section{Analisis Tambahan}

Berdasarkan hasil analisis terhadap rasio-rasio di atas, berikut analisis tambahan yang akan menjabarkan rasio-rasio yang saling berkaitan. Rasio-rasio yang saling berkaitan tersebut membahas mengenai beberapa hal.

Pertama mengenai kontrak pemain sepak bola. Rasio-rasio yang saling berkaitan membahas mengenai kontrak pemain sepak bola adalah current wages, investment in player contracts, cash received from selling player contract, net investment in player contracts, contract amortization rate dan intangible intensity. Transaksi pembelian pemain serta pembayaran kontrak pemain berhubungan dengan biaya gaji yang akan dibayar klub untuk kontrak pemain tersebut. Semakin banyak klub melakukan pembelian pemain dan pembayaran kontrak pemain, semakin banyak biaya gaji yang dibayar oleh klub tersebut. Transaksi penjualan dan pembelian pemain juga memengaruhi besarnya investasi bersih klub dalam kontrak pemain. Semakin banyak sebuah klub melakukan penjualan dan pembelian pemain, semakin besar investasi bersih klub dalam kontrak pemain. Contohnya pada Tottenham Hotspurs, Tottenham Hotspurs banyak melakukan penjualan dan pembelian pemain, sehingga investasi bersih Tottenham Hotspurs dalam kontrak 
pemain besar. Besarnya investasi bersih sebuah klub memengaruhi besarnya penyusutan dan proporsi kontrak pemain dalam aset. Semakin banyak klub melakukan investasi bersih dalam kontrak pemain, penyusutan kontrak pemain dan proporsi kontrak pemain tersebut di dalam aset semakin besar. Contohnya Tottenham Hotspurs yang memiliki investasi bersih dalam kontrak pemain yang besar, penyusutan kontrak pemain Tottenham Hotspurs juga besar, sebaliknya Arsenal yang memiliki investasi bersih dalam kontrak pemain kecil, penyusutan kontrak pemain Arsenal menjadi kecil.

Sementara yang kedua membahas mengenai kegiatan operasi. Rasio-rasio yang saling berkaitan membahas kegiatan operasi adalah current sales, operating profit before transfer fees dan adjusted cash flow from operation. Laba operasi sebuah klub dipengaruhi kegiatan operasi dan penjualan klub tersebut. Selain itu, kegiatan operasi juga memengaruhi arus kas operasi yang dihasilkan klub tersebut. Semakin baik kegiatan operasi klub dan penjualan klub akan semakin banyak laba operasi dan arus kas operasi yang dihasilkan klub tersebut. Contohnya Arsenal, penjualan Arsenal yang besar membuat laba operasi yang dihasilkan Arsenal juga besar. Hasil penelitian menemukan bahwa pendapatan terbesar Arsenal berasal dari penjualan tiket, sejalan dengan penelitian yang dilakukan oleh Hidayat (2010), yang menyebutkan bahwa sumber pemasukan terbesar Arsenal berasal dari penjualan tiket karena kapasitas stadionnya yang cukup besar dan harga tiket yang mahal.

Sedangkan yang ketiga membahas tentang aset. Rasio-rasio yang saling berkaitan membahas aset adalah adjusted leverage, total assets, asset turnover, rate of return to to assets dan current ratio. Besarnya aset klub sangat memengaruhi kelancaran klub dalam membayar kewajibannya. Investasi pada aset akan memengaruhi perputaran aset dan laba yang dihasilkan dari investasi tersebut. Semakin banyak sebuah klub melakukan investasi pada aset, perputaran aset tersebut semakin tidak lancar. Contohnya pada Arsenal, total aset Arsenal yang besar membuat perputaran aset Arsenal tidak lancar, berbeda dengan Everton yang memiliki total aset yang kecil perputaran asetnya lebih lancar.

Berdasarkan hasil analisis di atas, ditemukan bahwa hasil penelitian ini sejalan dengan hasil penelitian Amir dan Livne (2005) dan Hidayat (2010) bahwa pemain sepak bola memiliki peranan sangat penting kinerja keuangan klub sepak bola. Pemain sepak bola yang dapat diakui sebagai aset tidak berwujud, memengaruhi sebagian besar rasio-rasio keuangan klub sepak bola, baik terkait investasi, aset total, pendapatan, maupun beban, sehingga pada akhirnya juga mempegaruhi laba atau rugi klub. Hasil penelitian selanjutnya juga menemukan bahwa gaji pemain merupakan porsi terbesar beban di dalam laporan keuangan klub sepak bola. Selain itu, kinerja klub sepak bola juga dipengaruhi oleh berbagai sumber pendapatan yang diterima, baik terkait hak siar, penjualan tiket, komersial atau souvenir, ataupun pendapatan lainnya. 


\section{SIMPULAN DAN SARAN}

\section{Simpulan}

Dari hasil analisis dan pembahasan sebelumnya, dapat ditarik simpulan bahwa dari tiga klub sepak bola yaitu Arsenal, Tottenham Hotspurs dan Everton ditemukan secara umum Arsenal merupakan klub yang memiliki kinerja keuangan yang terbaik dibandingkan Tottenham Hotspurs dan Everton, khususnya dalam hal pendapatan dan likuiditas. Arsenal memiliki kinerja keuangan yang baik karena penjualannya, terutama dari penjualan tiket selalu lebih besar dari beban operasi yang dikeluarkan. Selain itu, Arsenal menerapkan strategi pengembangan pemain muda dan jarang melakukan jual beli pemain sehingga lebih efisien dalam menggunakan pendapatannya. Arsenal juga ditemukan memiliki likuiditas paling baik karena paling mampu menutupi hutang lancarnya dengan aset lancar yang dimiliki.

Tottenham Hotspurs memiliki keunggulan dalam hal investasi bersih atas kontrak pemain dan arus kas operasi. Klub ini memiliki sumber pendapatan terbesar dari hak siar dan paling sering melakukan transaksi jual-beli pemain, sehingga investasi bersih Tottenham Hotspurs pada kontrak pemain adalah yang paling besar. Tottenham Hotspurs juga memiliki arus kas operasi yang paling baik di antara yang lain, karena memiliki kegiatan operasi klub dan penjualan. Sedangkan Everton secara umum memiliki kinerja keuangan yang terburuk dalam hal operasional. Memburuknya kinerja keuangan klub ini karena beban operasi terutama beban gaji yang selalu lebih besar dari penjualannya, sehingga menyebabkan Everton selalu mengalami kerugian. Selain itu, di antara klub lainnya Everton memiliki risiko likuiditas tertinggi, namun memiliki perputaran aset yang baik.

Dari 14 rasio keuangan yang digunakan dalam penelitian ini, juga ditemukan bahwa secara umum kinerja keuangan klub sepak bola banyak dipengaruhi oleh pemain, baik dalam hal aset, pendapatan, beban maupun investasi. Hasil penelitian ini dapat memberikan implikasi praktis bagi klub sepak bola di Indonesia yang belum memiliki laporan keuangan untuk membuat laporan keuangan, walaupun tidak serumit yang dilakukan ketiga klub dalam penelitian ini, tetapi akan sangat membantu dalam melakukan evaluasi kinerjanya. Saran bagi lembaga atau federasi sepak bola, misalnya FIFA akan lebih baik untuk dibuat aturan mengenai laporan keuangan klub sepak bola yang lebih jelas karena walaupun sudah ada peraturan dari FIFA tetapi kurang menjelaskan pada akun-akun secara mendetail.

\section{Keterbatasan dan Saran untuk Penelitian yang Akan Datang}

Penelitian ini memiliki keterbatasan penelitian yaitu akses data yang terbatas untuk mendapatkan laporan keuangan dari klub sepak bola lainnya, sehingga tidak dapat mewakili semua klub sepak bola yang ada. Selain itu, penelitian ini hanya menganalisis berdasarkan data berupa laporan keuangan saja. Penelitian mendatang disarankan untuk menggunakan sampel klub sepak bola yang lebih banyak di negara 
lain, misalnya Indonesia dan menggunakan sumber data untuk menganalisis selain laporan keuangan seperti data non keuangan jika dimungkinkan. Hal ini dilakukan agar diperoleh hasil penelitian yang lebih baik dan lebih mewakili gambaran kinerja klub sepak bola.

\section{DAFTAR PUSTAKA}

Amir, E., dan L. Gilad. 2005. Accounting, valuation and duration of football player contracts. Journal of Business Finance \& Accounting. Vol.32. Available at www.cassknowledge.com.

Arronson, S., J. Karolina, dan J. Frida. 2004. Accounting for football club-Let's give it a shoot, a delineation of financial statements within Swedish football club. Bachelor Tesis. Goteborg University School of Economics and Commercial Law. Available at www.searchebsco.com.

Deloitte. 2010. Financial reporting framework in Italy. Available at http://www.sepaxbola.info/2011/02/mengukur-pendapatan-klub-klub-besar.

FIFA. 2007. Club licensing regulation. Available at www.FIFA.com.

Hidayat, R. T. 2010. Analisis atas laporan keuangan klub sepak bola: Studi pada klub arsenal, juventus dan barcelona. Tesis. Magister Akuntansi Fakultas Ekonomi Universitas Indonesia. Available at www.lontarui.ac.id.

International Accounting Standard Board. 1998. International accounting standard No.38: Intangible assets. London, UK.

Kurniawan, A. 2007. Analisis kinerja keuangan pemerintah daerah kabupaten kudus tahun 2001-2006. Skripsi. Fakultas Ekonomi Akuntansi Universitas Kristen Satya Wacana. tidak dipublikasikan.

OPPapers.com. Accounting for football club. Available at http://www.Oppapers.com/Essays/Accounting-Football-Club.

2011. Asal muasal sepak bola. Available at http://duniabaca.com/asalmuasal-sejarah-sepak-bola.html.

2011. Kenapa liga inggris disebut yang terbaik di dunia?. Available at http://olahraga.kompasiana.com/bola.

- 2011. Mengukur pendapatan klub-klub besar eropa. Available at http://www.sepaxbola.info/2011.

2006. Most popular sport in the world. Available at http://mostpopular.net/Sport-Played-World. 